\title{
Generic names in the Orbiliaceae (Orbiliomycetes) and recommendations on which names should be protected or suppressed
}

\author{
Hans-Otto Baral ${ }^{1}$ - Evi Weber ${ }^{1}$ - Walter Gams ${ }^{2}$ - Gregor Hagedorn ${ }^{3}$ - Bin Liu ${ }^{4}$. \\ Xingzhong Liu ${ }^{5} \cdot$ Guy Marson $^{6}$ - Ludmila Marvanová ${ }^{7}$ Marc Stadler $^{8}$. \\ Michael Weiß ${ }^{9,10}$
}

Received: 4 October 2016 /Revised: 8 March 2017 / Accepted: 20 March 2017 / Published online: 17 May 2017

(C) The Author(s) 2017. This article is an open access publication

\begin{abstract}
A list of all generic names that have been connected with the Orbiliomycetes is provided. Recommendations are made as to which names should be used in accordance with the rules and the different generic concepts. There is a mismatch in the current generic concepts within Orbiliomycetes regarding the two morphs: a narrow concept is used for the asexual morphs, but a broad concept relies on the sexual morphs. As a consequence, many more generic names have been established for the asexual morphs. A number of previous generic concepts are artificial, since they were based on single characters without molecular support. In order to
\end{abstract}

Section Editor: Roland Kirschner

The last eight authors are listed alphabetically, contributing by phylogenetic results or in advisory capacity.

This article is part of the "Special Issue on ascomycete systematics in honour of Richard P. Korf who died in August 2016".

Electronic supplementary material The online version of this article (doi:10.1007/s11557-017-1300-6) contains supplementary material, which is available to authorized users.

Hans-Otto Baral

zotto@arcor.de

1 Blaihofstr. 42, 72074 Tübingen, Germany

2 Molenweg 15, 3743 CK Baarn, The Netherlands

3 Museum für Naturkunde, Leibniz-Institut für Evolutions- und Biodiversitätsforschung, Invalidenstraße 43, 10115 Berlin, Germany

4 Institute of Applied Microbiology, Agricultural College of Guangxi University, Nanning 530005, China

5 State Key Laboratory of Systematic Mycology and Lichenology, Institute of Microbiology, Chinese Academy of Sciences, P.O. Box 2714, Beijing 100080, China provide solutions for this mismatch, we present three different generic concepts within the Orbiliomycetes. A broad concept recognizes a large genus Orbilia, with which most of the listed names fall into synonymy, but could be maintained as infrageneric names. Due to the lack of data proving phylogenetic relationships, this broad concept, at present, is the most practicable and recommended one. A moderate concept subdivides Orbilia into several genera, with all nematodetrapping fungi merged in Arthrobotrys. A narrow generic concept accepts genera based on differences in trapping organs, but also subdivides the remaining groups of Orbilia into

6 Division of Mycology, Museum of Natural History, 25 rue Münster, 2160 Luxembourg City, Luxembourg

7 Czech Collection of Microorganisms, Institute of Experimental Biology, Masaryk University, 62500 Brno, Czech Republic

8 Department Microbial Drugs, Helmholtz-Zentrum für Infektionsforschung $\mathrm{GmbH}$, Inhoffenstrasse 7, 38124 Braunschweig, Germany

9 Steinbeis-Innovationszentrum, Organismische Mykologie und Mikrobiologie, Vor dem Kreuzberg 17, 72070 Tübingen, Germany

10 Fachbereich Biologie, Universität Tübingen, Auf der Morgenstelle 28, 72076 Tübingen, Germany 
additional genera. Trapping of invertebrates (zoophagy) is not restricted to Arthrobotrys in a broad sense, but occurs also in the more distant basal genera Hyalorbilia and Lecophagus, which mainly prey on rhizopods and rotifers. Whether these predatory capabilities trace back to a common ancestor is not clear. The following new combinations are proposed: Hyalorbilia oviparasitica, Hyalorbilia quadridens, Hyalorbilia tenuifusaria, and Orbilia fissilis.

Keywords Arthrobotrys · Hyalorbilia $\cdot$ Lecophagus · Orbilia $\cdot$ Vermispora $\cdot$ Nematode trapping · Nomenclature . Phylogeny $\cdot$ Stauroconidia

\section{Introduction}

Previously assigned to the Helotiales, an order today recognized in the Leotiomycetes, the family Orbiliaceae was raised to the rank of a class, Orbiliomycetes, based on morphological as well as molecular phylogenetic data (Eriksson et al. 2003). The class forms a monophyletic group that occupies a rather basal position within the Ascomycota close to the Pezizomycetes. The main characteristic of the sexual morph is a striking plasmatic structure of the ascospores, the "spore body" (Fig. 2), which is well visible only in the vital state. This vacuolar organelle occurs mostly in the spore apex, more rarely in both ends of the spore. It shows a high morphological diversity among the taxa, varying between lens-shaped, globose, tear-shaped, rod-shaped, and vermiform (straight or flexuous). Further peculiarities of many species of the class involve the ability to trap invertebrates, including protozoa, by means of specialized trapping organs, the connection to some genera of Ingoldian hyphomycetes as asexual morphs, and a high desiccation tolerance of both asexual and sexual morphs.

A serious deficit in previous taxonomic treatments became obvious in the huge number of new species to be described in the monograph in preparation (H.O. Baral, E. Weber \& G. Marson, unpubl.). Most of the previously published taxonomic, cultural, and molecular phylogenetic work on the class has been done on the basis of taxa from permanently moist (hygric) or wet (semi-aquatic) environments, but many, mostly undescribed taxa from xeric substrates, which are dry for most of the season, were missing in public fungaria, culture collections, and sequence databases. The ongoing monographic treatment of the class has revealed many misidentifications in such repositories. This is due to the paucity of previous monographic work, especially on the sexual morph. The naming of samples is complicated by inadequate descriptions, which often offer very different interpretations of a species.

Connections between sexual and asexual morphs within the Orbiliomycetes have been known since the end of the 19th century (Brefeld 1891, Dicranidion), but most connections have been discovered since the end of the 20th century, starting with Pfister's (1997) comprehensive study. Scholler et al. (1999) and Hagedorn and Scholler (1999) introduced a new generic concept for asexual morphs of nematode-trapping orbiliaceous fungi based on the types of trapping organs rather than the morphology of conidia and conidiophores. Together with molecular phylogenetic data, the new concept appears sound for those taxa that produce trapping organs in culture. Trapping organs adapted to nematode capture are either adhesive traps or involve constricting or non-constricting rings. Some taxa with adhesive organs capture arthropods such as copepods, mites, collembolans, and dipterans. All these predacious taxa treated by Scholler et al. (1999) are members of Arthrobotrys in a broad sense, a subgroup of Orbilia s. 1.

Two further genera of Orbiliomycetes that possess trapping organs were not treated by Scholler et al. (1999): Brachyphoris (the asexual morph of Hyalorbilia, earlier classified in Dactylella) and Lecophagus. Their members trap rhizopods, or rotifers and tardigrades, respectively, through the prey's mouth region by means of adhesive pegs or knobs. One species (Brachyphoris oviparasitica) is known to parasitize nematode eggs, a behavior occurring also in the closely related genus Vermispora. In our molecular phylogenetic analyses (Fig. 1), the two genera cluster in basal clades and might originate from a common ancestor with predacious capabilities. Arthrobotrys s. 1. does not seem to be closely related to this clade; therefore, it is unclear whether it developed zoophagy independently.

In the ongoing work on the monograph, predacious capabilities could not be demonstrated in pure culture for the majority of species up to now. The aforementioned classification system based on trapping organs does not offer a solution for all those apparently non-predacious taxa. Unpublished morphological data together with the present molecular phylogenetic hypothesis (Fig. 1) suggest that these taxa can be classified into various groups, most of which appear only distantly related to the predacious groups. Due to the absence of trapping organs, their classification is mainly based on characters of the sexual morph and rDNA data, and, to a certain extent, also on conidial morphology. In some of the groups (e.g., Pseudotripoconidium vs. Helicoon/Anguillospora), the conidial morphology is highly characteristic, whereas the sexual morph is hardly distinctive.

The heterogeneity of most non-predacious asexually typified genera is exemplified by those with stauroconidia that are distinguished according to different types of branching. Cultural studies have shown that different branching types often occur within a single isolate (see, e.g., Ando 1992) or in very closely related species. We found representatives of most of these asexually typified genera, for instance Trinacrium and Dicranidion, in distant clades within the class, and evidence is accumulating that the current generic concept is artificial. Two of these genera, Dwayaangam and Anguillospora, also include taxa belonging to the Helotiales (e.g., D. colodena Sokolski \& Bérubé and A. crassa Ingold) or Dothideomycetes [e.g., A. rubescens Gulis \& Marvanová and A. longissima (Sacc. \& 
P. Syd.) Ingold]. These asexual morphs are morphologically difficult to distinguish from their orbiliaceous analogues.

Under the new nomenclature rules, we see two aspects of handling asexually typified genera without known trapping organs. We can either regard these conidium-based "genera" just as descriptive terms. According to recommendations by Seifert et al. (2000), Cannon and Kirk (2000), and Hawksworth (2011), it is convenient to use phrases such as "anguillospora-like" when referring to a given morphology, irrespective of the phylogenetic relationship. Or we have to determine which of these asexually typified generic names can be used in a phylogenetic sense as a holomorph name for a given genus, depending on the position of its type species.

The following alphabetic list treats all generic names that we found to be connected with the Orbiliomycetes. Several names are obligate, homotypic synonyms of others, and many are heterotypic synonyms even when a narrow generic concept is applied. However, the identity of a type species, particularly that of asexually typified genera, is often uncertain when no DNA sequences are available because of convergences, especially in conidial shape.

Below, we have indicated our opinion on all those generic names that compete with a name of a different or the same morph, addressing which name should be used in accordance with the rules and the chosen generic concept. Studies of connections of asexual and sexual morphs within the last several decades have shown that the generic concepts applied up to now are very inconsistent between the two morphs: a narrow concept has been applied to the asexual morph but a broad concept to the sexual morph. As a result, we are dealing with many more generic names that are based on asexual morphs.

We see three main ways of handling the ranks within the class (Table 1). (1) When applying a broad generic concept, most of the listed generic names fall into synonymy with the oldest name of an orbiliaceous sexual morph, Orbilia, published by Fries in 1836. Apart from three small undescribed genera, two of which are included in our phylogenetic analysis (Fig. 1), this concept recognizes five genera with very different species numbers: Hyalorbilia ( 40), Lecophagus ( 5), Orbilia ( 500), Pseudorbilia (1), and Vermispora ( 7, including Microdochiella) (the species numbers given here include undescribed taxa). The large genus Orbilia is subdivided into a system of subgenera, sections, and series. This broad concept is represented in Fig. 1. It is applied in the ongoing monograph of Orbiliomycetes, because many species of Orbilia s. 1. are at present without molecular data, and because available rDNA data in various cases did not result in significantly supported clades that reflect morphology-based concepts.

(2) A moderate generic concept subdivides the large genus Orbilia into a number of genera. For instance, the following four names could be recognized: Arthrobotrys, Habrostictis, Hemiorbilia, and Orbilia. Arthrobotrys, published by Corda in 1839 , is the oldest available name for an orbiliaceous
Table 1 Three generic concepts within Orbilia. A broad concept is used in the "Monograph of Orbiliomycetes" (Baral et al., unpubl.)

\begin{tabular}{|c|c|c|}
\hline Broad concept & Moderate concept & Narrow concept \\
\hline $\begin{array}{l}\text { Orbilia } \\
\text { subgenus Hemiorbilia } \\
\text { section Hemiorbilia } \\
\text { section Lentiformes* }\end{array}$ & $\begin{array}{l}\text { Hemiorbilia* } \\
\text { subgenus Hemiorbilia } \\
\text { subgenus Lentiformes* }\end{array}$ & $\begin{array}{l}\text { Hemiorbilia } \\
\text { Lentiformes* }\end{array}$ \\
\hline $\begin{array}{l}\text { subgenus Habrostictis } \\
\text { section Habrostictis } \\
\text { section Helicoon } \\
\text { section Aurantiorubrae* }\end{array}$ & $\begin{array}{l}\text { Habrostictis } \\
\text { subgenus Habrostictis } \\
\text { subgenus Helicoon } \\
\text { subgenus Aurantiorubrae* }\end{array}$ & $\begin{array}{l}\text { Habrostictis } \\
\text { Helicoon } \\
\text { Aurantiorubrae* }\end{array}$ \\
\hline $\begin{array}{l}\text { subgenus Orbilia } \\
\text { section Orbilia } \\
\text { section Ovoideae* }\end{array}$ & $\begin{array}{l}\text { Orbilia } \\
\text { subgenus Orbilia } \\
\text { subgenus Ovoideae* }\end{array}$ & $\begin{array}{l}\text { Orbilia } \\
\text { Ovoideae* }^{*}\end{array}$ \\
\hline $\begin{array}{l}\text { section Arthrobotrys } \\
\text { series Arthrobotrys } \\
\text { series Dactylella } \\
\text { series Dactylellina } \\
\text { series Drechslerella } \\
\text { series Gamsylella }\end{array}$ & $\begin{array}{l}\text { Arthrobotrys } \\
\text { subgenus Arthrobotrys } \\
\text { subgenus Dactylella } \\
\text { subgenus Dactylellina } \\
\text { subgenus Drechslerella } \\
\text { subgenus Gamsylella }\end{array}$ & $\begin{array}{l}\text { Arthrobotrys } \\
\text { Dactylella } \\
\text { Dactylellina } \\
\text { Drechslerella } \\
\text { Gamsylella }\end{array}$ \\
\hline
\end{tabular}

* at present unpublished name

asexual morph, and, under this concept, it would encompass all nematode-trapping species, as well as some closely related non-nematophagous species (Dactylella p.p.). (3) A narrow generic concept accepts the system proposed by Scholler et al. (1999) for the nematode-trapping group and also subdivides the remaining three genera of the moderate generic concept into various further genera.

The moderate as well as the narrow generic concept require a classification system that includes ranks above the generic level. The phylogenetic analysis presented here is based on rDNA alone, because data from protein-coding genes were not available for the majority of taxa. Therefore, the resulting tree topology shows high support only for its terminal branches and leaves the backbone of the tree unresolved.

In the notes on each generic name, we have mentioned the three main generic concepts whenever the acceptance of a name depends on the taxonomic concept chosen. Table 3 lists the recommended generic names and those names of either the sexual or the asexual morph that are considered synonymous even under a narrow concept. If action is required, this is mentioned in the last column.

\section{Materials and methods}

The origin of fungal material will be reported in detail in the monograph in preparation. For the microscope techniques, see Baral (1992). Sequences were either gained from our cultures, for which half-strength cornmeal agar (CMA:2, Rubner 1996) was used, or from apothecia, using standard techniques for DNA extraction, PCR, and Sanger sequencing (e.g., Quijada 


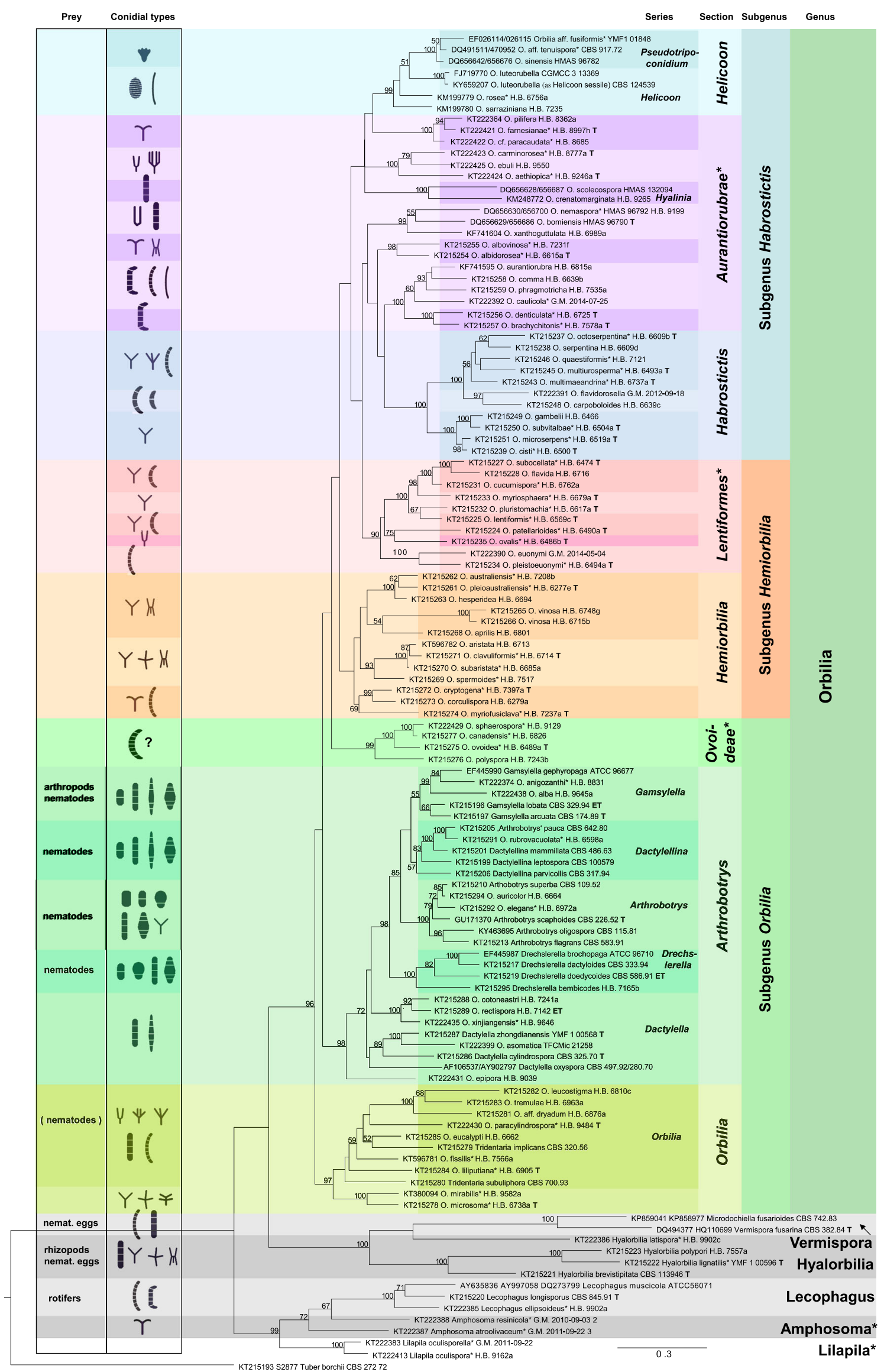


Fig. 1 Maximum likelihood tree illustrating phylogenetic relationships in the Orbiliomycetes as inferred from a $1854 \mathrm{bp}$ alignment of nuclear DNA sequences (18S, 5.8S, and 28S). Branch support is given as maximum likelihood bootstrap percentages from 1000 replicates; values below 50\% are not shown. Branch lengths are given in terms of expected numbers of substitutions per nucleotide. GenBank accession numbers are given in the tree for each DNA sequence used. The tree was rooted with Tuber borchii. A broad taxonomic concept is shown that includes different subgenera, sections, and series (the latter are only mentioned when published names are available); *generic, infrageneric, and species names that will be validly published in the "Monograph of Orbiliomycetes" (Baral et al., unpubl.); $\mathrm{T}=$ type; ET = epitype; for an explanation of the conidial symbols, see Table 2

et al. 2014) with various primers. The following abbreviations are used: $(\mathrm{A})=$ asexual morph (= anamorph), $(\mathrm{S})=$ sexual morph (= teleomorph), H.B. = private fungarium H.-O. Baral.

\section{Molecular phylogenetic analysis}

Nuclear rDNA sequences comprising partial 18S, ITS, and 28S rDNA were aligned using MAFFT 7 (Katoh and Standley 2013) via a web server at http://mafft.cbrc.jp/ alignment/server/. Gappy alignment blocks caused by inserts in single sequences were excluded. Misaligned isolated sequence fragments in the leading or trailing regions of the alignment were recoded (masked) as missing data, as were

Table 2 Conidial symbols as used in Fig. 1

\begin{tabular}{|l|l|}
\hline Explanation \\
\hline
\end{tabular}$\quad$\begin{tabular}{l} 
Conidia straight, none-septate \\
\hline
\end{tabular}

two short strings of three or nine nucleotides, respectively, which apparently had been misaligned because of sequencing errors. The final dataset (alignment) had a length of 1854 nucleotides (see the supplementary material). The alignment is also deposited in TreeBASE (http://www.treebase/org, accession number S20839). We ran five separate heuristic maximum-likelihood analyses using RAxML version 8.2.4 (Stamatakis 2014), as implemented in a parallelized version at the CIPRES portal (http://www.phylo.org), each time involving four processors and the GTRCAT model of DNA substitution, with starting trees in each replicate obtained from 1000 rounds of rapid bootstrapping ( $-f a$ option), and different starting seeds. The tree with the highest likelihood inferred in these analyses is shown in Fig. 1.

\section{Checklist of genera of Orbiliomycetes}

Anguillospora Ingold, Trans. Br. Mycol. Soc. 25(4): 401 (1942) ["1941"] — Use Anguillospora (A) only in the form of "anguillospora-like" when referring to conidial shape; use instead Helicoon (A) when applying a narrow generic concept, otherwise use Habrostictis (S) or Orbilia (S).

Anguillospora was based on A. longissima, which had originally been described in Fusarium. Index Fungorum (http:// www.indexfungorum.org) lists a total of 20 names, but only for one of them, A. rosea, could a relationship with Orbiliomycetes be demonstrated (Webster and Descals 1979; Descals and Chauvet 1992; Descals et al. 1999, as Orbilia sp.; Pfister 1997, as O. luteorubella (Nyl.) P. Karst.).

Anguillospora was characterized by filiform (scolecosporous), multiseptate, hyaline conidia that resemble an eel (= anguilla). Examples belonging to Orbiliomycetes are shown in Fig. 3h, i. The morphological delimitation from asexual morphs with shorter conidia referable to Vermispora is only gradual concerning conidial shape, though Vermispora can be separated from Anguillospora by a sympodial conidiogenesis. Lecophagus differs by sympoduloconidia formed almost simultaneously in fascicles on multilocular conidiophore tips (Fig. 3g).

That Anguillospora is heterogeneous was noticed early based on different patterns of conidial secession and connections to very different sexual morphs (Webster and Descals 1979; Nakagiri and Tubaki 1983; Descals et al. 1999). Species of Anguillospora also differ in their microconidial synanamorph: non-orbiliaceous members often have subglobose, non-septate microconidia formed on phialides, whereas orbiliaceous members form microconidia similar to the macroconidia: elongate, septate, holoblastic. This heterogeneity has been confirmed by molecular studies (Belliveau and Bärlocher 2005; Baschien et al. 2006). Accordingly, the former concept of 
Anguillospora encompasses five different ascomycete orders (Dothideales, Pleosporales, Lulworthiales, Helotiales, Orbiliales).

Conidial secession in the type species A. longissima is rhexolytic, i.e., with a separating cell that splits during secession, though this feature is best seen only shortly after secession, and is hardly visible in some of the published illustrations. In perhaps all of the remaining species conidial secession is schizolytic, i.e., without such a separating cell (Baschien et al. 2006). In taxa of the genus connected to helotialean sexual morphs, the conidiogenous cells have been reported to be thalloblastic-percurrent (Baschien et al. 2013). Pycnidal synanamorphs were found in Anguillospora longissima (Willoughby \& Archer 1973) and in A. mediocris J. Gönczöl \& Marvanová (Gönczöl and Marvanová 2002), whereas moniliaceous phialidic synanamorphs were observed in A. crassa (Webster 1961) and A. furtiva Descals (Descals et al. 1999). Besides a pycnidial synanamorph, Webster and Descals (1979) report a tiny phialidic synanamorph with simple conidiophores in A. longissima. In those anguillosporalike asexual morphs that we found to be connected to orbiliaceous sexual morphs, neither rhexolytic conidial secession nor percurrent proliferation or formation of phialidic microconidia have been observed. However, Baschien et al. (2006) and Descals et al. (1999) stated that A. rosea also shows percurrent proliferation, and L. Marvanová observed this feature in her isolates of $A$. rosea.

In the unpublished monograph, anguillospora-like asexual morphs are reported from ascospore isolates of a few teleomorphic species, particularly those adapted to an aeroaquatic habitat (section Helicoon, including $A$. rosea). Since A. longissima was shown to belong in Amniculicola Y. Zhang ter \& K.D. Hyde, Dothideomycetes (Belliveau and Bärlocher 2005; Zhang et al. 2007), the genus Helicoon s. str. can be used to also include $A$. rosea, which is phylogenetically closely related to the type species $H$. sessile. A recent proposal (Rossman et al. 2016) recommends to protect Amniculicola over Anguillospora, or to conserve Anguillospora with a new type.

Anulosporium Sherb. (1933) - Use Dactylellina (A) instead of the dubious older name Anulosporium (A) when applying a narrow generic concept, otherwise use Arthrobotrys (A) or Orbilia (S).

The genus Anulosporium was proposed for A. nematogenum, and no further species have been added later. It is characterized by stalked adhesive knobs and non-constricting rings and is, therefore, a clear earlier synonym of Dactylellina. However, its author (Sherbakoff 1933) misinterpreted the stalks as conidiophores, the rings as conidia, and the knobs as early stages of the rings. Because no true conidia were observed, the identity of the type species remains unclear. For this reason,
Scholler et al. (1999) considered the genus to be dubious, an opinion with which we agree.

Arthrobotrys Corda (1839) - Use Arthrobotrys (A) when applying a moderate or narrow generic concept, otherwise use Orbilia (S).

Arthrobotrys (Figs. 4j, n-p and 5f), which was described with the single species $A$. superba, is one of the largest orbiliaceous genera and also represents the most widely used generic name within the Orbiliomycetes. 105 specific epithets have ever been combined in Arthrobotrys (Index Fungorum), but many of them were shown to be synonyms, which illustrates the complicated taxonomy in this group. For instance, A. superba, A. cladodes Drechsler, and A. oligospora form a difficult complex of species to which Orbilia auricolor agg. was shown to be connected as the sexual morph (Figs. $2 \mathrm{~m}$ and 4o, p).

Some Arthrobotrys species (in particular A. oligospora, Fig. 4p) have been used as model organisms in attempts to develop biocontrol agents and in mycology teaching. It is, therefore, desirable to preserve this name under the new rules. Earlier, the genus was defined by 1-septate conidia formed in roundish clusters on nodules on swollen fertile nodes ("arthrobotryoid" conidiogenesis), combined with the ability to trap nematodes, though without respect to the type of trapping organs. Schenck et al. (1977) extended the generic definition to include species with aseptate and multiseptate conidia and candelabrelloid conidiophores. The Greek suffix botrys describes the clusters of conidia and the prefix arthrorefers to the chain-like arrangement of the clusters along the very elongate conidiophore in the type species.

The ICN contains a new passage [Art. 62.2(a)] that all names ending in -botrys are treated as masculine. There are, however, a range of fungal genera that have always been treated as feminine in accordance with Botrytis, which will require a modification of the Code. We, therefore, do not follow the new rule.

The concept of Scholler et al. (1999) accepts 46 species in Arthrobotrys, all of which trap nematodes by means of more or less three-dimensional adhesive networks (Fig. 5f). Based on this concept, the authors considered eight further generic names as synonymous (see below), which include species possessing conidiophores with a single acrogenous conidium, and conidia varying from cylindric-clavate to fusiform. A sexual morph name (Orbiliella) and a questionable asexual morph name (Tripoconidium) are here added to the list of synonyms. The genus is represented in Fig. 1 as the Arthrobotrys clade within the section Arthrobotrys.

Orbilia, with currently about 80 validly described and accepted species, was erected three years earlier than Arthrobotrys, with about 60 species. When applying a broad generic concept, Orbilia should be preferred because of its priority and larger species number. Both genera have 
Table 3 Recommended generic names of Orbiliomycetes and their synonyms that compete for use

$\begin{array}{lll}\text { Recommended generic name } & \begin{array}{l}\text { Synonymous alternate morph generic } \\ \text { name }\end{array} & \text { Additional synonymous generic names Action required }\end{array}$

Arthrobotrys Corda, Pracht-Fl. Eur. Schimmelbild.: 43 (1839) - Type species: A. superba Corda (1839) [?= Orbilia auricolor (A. Bloxam) Sacc. (1889)] (use when applying a moderate or narrow generic concept, otherwise use Orbilia)
Orbiliella Kirschst., Ann. Mycol. 36: 374 (1938) - Type species: O. armeniaca Kirschst. (1938) [= Orbilia auricolor (A. Bloxam) Sacc. (1889)]
Monacrosporium Oudem., Ned. Kruidk. Arch., Ser. 2,4: 250 (1885) - Lectotype species: M. elegans Oudem. (1885) [” Arthrobotrys oudemansii M. Scholler et al. (2000)]

Didymozoophaga Soprunov \& Galiulina, Mikrobiologiya 20: 493 (1951) [nom. inval., Art. 39] - Lectoype:

D. oligospora (Fresen.) Soprunov \& Galiulina, basionym: Arthrobotrys oligospora Fresen

Candelabrella Rifai \& R.C. Cooke, Trans. Br. Mycol. Soc. 49(1): 160 (1966) - Type species: C. javanica Rifai \& R. C. Cooke (1966) [” Arthrobotrys javanica (Rifai \& R.C. Cooke) Jarow. (1970)]

Genicularia Rifai \& R.C. Cooke, Trans. Br. Mycol. Soc. 49: 153 (1966) [nom. illegit., Art. 53 ICN] - Type species: G. cystosporia (Dudd.) Rifai \& R.C. Cooke, basionym: Trichothecium cystosporium Dudd. [三 Arthrobotrys cystosporia (Dudd.) Mekht.]

Duddingtonia R.C. Cooke, Trans. Br. Mycol. Soc. 53: 316 (1969) - Type species: D. flagrans (Dudd.) R.C. Cooke (1969), basionym: Trichothecium flagrans Dudd. [三 Arthrobotrys flagrans (Dudd.) Mekht. (1964)]

Geniculifera Rifai, Mycotaxon 2: 214 (1975) - Type species: G. cystosporia (Dudd.) Rifai (1975), basionym: Trichothecium cystosporium Dudd. [” Arthrobotrys cystosporia (Dudd.) Mekht. (1964)]

Nematophagus Mekht., Mikol. Fitopatol. 9(2): 250 (1975) - Type species: N. azerbaijanicus Mekht. (1975) [三 Arthrobotrys azerbaijanica (Mekht.) Oorschot (1985)]

Monacrosporiella Subram., Kavaka 5: 94 (1978, "1977”) - Type species: M. megalospora (Drechsler) Subram. (1978), basionym: Dactylella megalospora Drechsler [ [ Arthrobotrys megalospora (Drechsler) M. Scholler et al. (1999)]

?Tripoconidium Subram., Kavaka 5: 95 (1978) - Type species: T. aphanopagum (Drechsler) Subram. (1978), basionym: Triposporina aphanopaga Drechsler

Woroninula Mekht., Khishchnye Nematofagovye Griby-Gifomitsety: 109 (1979) - Type species: W. polycephala (Drechsler) Mekht. (1979), basionym: Dactylaria polycephala Drechsler [三 Arthrobotrys polycephala (Drechsler) Rifai (1968)]
Asexual type. Approval needed by Nomenclature Committee for Fungi 
Table 3 (continued)

Dactylella Grove, J. Bot. 22: 199 (1884) Type species: D. minuta Grove (1884) (use when applying a narrow generic concept, otherwise use Arthrobotrys or Orbilia)

Dactylellina M. Morelet, Bull. Soc. Sci. Nat. Archéol. Toulon Var 178: 6 (1968)

- Type species: D. leptospora (Drechsler) M. Morelet (1968), basionym: Dactylella leptospora Drechsler (1937) (use when applying a narrow generic concept, otherwise use Arthrobotrys or Orbilia)
Drechslerella Subram., J. Indian Bot. Soc. 42: 299 (1964) [“1963”] - Type species: D. acrochaeta (Drechsler) Subram. (1964), basionym: Dactylella acrochaeta Drechsler (1952) (use when applying a narrow generic concept, otherwise use Arthrobotrys or Orbilia)

Roigiella R.F. Castañeda, Revta Jardín bot. Nac., Univ. Habana 5(1): 62 (1984) - Type species: R. lignicola R.F. Castañeda (1984) (= Arthrobotrys sp. fide Seifert et al. 2011)

Gangliophragma Subram., Kavaka 5: 94 (1978, "1977”) - Type species: G. rhopalota (Drechsler) Subram. (1978), basionym: Dactylella rhopalota Drechsler (1943)

Drechsleromyces Subram., Kavaka 5: 93 (1978, “1977”) - Type species: D. atractoides (Drechsler) Subram. (1978), basionym: Dactylella atractoides Drechsler (1943)

?Dactylium Nees, Syst. Pilze: 58 (1816) Reject [1816-1817], Fr., Syst. Mycol. 3: 382, 412 (1832), nom. dub. - Type species: D. candidum Nees [nom. dub. et rej.; ?non Dactylaria candida (Nees) Sacc. s. Drechsler (1937: 523), = Dactylellina haptotyla (Drechsler) M. Scholler et al.]

Anulosporium Sherb., Mycologia 25: 262 (1933) - Type species: A. nematogenum Sherb. (1933) (nom. dub., identity unclear at the species level)

Dactylosporium Mekht., Mikol. Fitopatol. 1: 277 (1967), nom. illegit., Art. 53 ICN [non Dactylosporium Harz 1871] - Type species: D. leptosporum (Drechsler) Mekht., basionym: Dactylella leptospora Drechsler [ [ (Drechsler) M. Morelet (1968)]

Laridospora Nawawi, Trans. Br. Mycol. Soc. 66: 344 (1976) - Type species: L. appendiculata (Anastasiou) Nawawi (1976), basionym: Dactylella appendiculata Anastasiou (1964) [三 Dactylellina appendiculata (Anastasiou) M. Scholler et al. (1999)] Kafiaddinia Mekht. Mikol. Fitopatol. 12: 8 (1978) - Type species: K. fusarispora Mekht. (1978) (= Dactylellina leptospora fide Rubner 1996)

Orbiliaster Dennis, Kew Bull. 9: 294 (1954) - Type species: O. pilosus Dennis (1954) [三 Orbilia pilosa (Dennis) Baral (1994)]
Dactylariopsis Mekht., Mikol. Fitopatol. 1: 278 (1967) - Type species:

D. brochopaga (Drechsler) Mekht. (1967), basionym: Dactylella brochopaga Drechsler (1937) [三 Drechslerella brochopaga (Drechsler) M. Scholler et al. (1999)]

Golovinia Mekht., Mikol. Fitopatol. 1: 275 (1967) - Type species: G. bembicodes (Drechsler) Mekht. (1967), basionym: Dactylella
Later name proposed for protection 
Table 3 (continued)

Recommended generic name

Synonymous alternate morph generic

Additional synonymous generic names

Action required name

bembicodes Drechsler (1937) [

Drechslerella bembicodes (Drechsler)

M. Scholler et al. (1999)]

Gamsylella M. Scholler, Hagedorn \& A. Rubner, Sydowia 51(1): 108 (1999) Type species: G. arcuata (Scheuer \& J. Webster) M. Scholler et al. (1999), basionym: Dactylella arcuata Scheuer \& J. Webster (1990) (use when applying a narrow generic concept, otherwise use Arthrobotrys or Orbilia)

Habrostictis Fuckel, Jahrb. Nassau. Ver. Naturkd. 23-24: 249 (1870) - Type species: H. rubra Fuckel (1870) [= Orbilia carpoboloides (P. \& H. Crouan) Baral (1994)] (use when applying a moderate or narrow generic concept, otherwise use Orbilia)

Helicoon Morgan, J. Cincinnati Soc. Nat. Hist. 15: 49 (1892) - Lectotype species: H. sessile Morgan (1892) (use when applying a narrow generic concept, otherwise use Habrostictis or Orbilia)

Orbilia subgenus Hemiorbilia Baral, Syst. Ascomycetum 13: 118 (1994) Type species: O. occulta (Rehm) Sacc. (1889), basionym: Calloria occulta Rehm (1885) (raise Hemiorbilia to generic rank when applying a moderate or narrow generic concept, otherwise use Orbilia)

Hyalorbilia Baral \& G. Marson, Micologia 2000 (Trento): 44 (2001) Type species: H. berberidis (Velen.) Baral (2001), basionym: Orbilia berberidis Velen. (1934)
?Trinacrium Riess in Fresenius, Beitr. Mykol. 2: 42 (1852) - Type species: T. subtile Riess (1852)

Dwayaangam Subram., Kavaka 5: 96 (1978) - Type species: D. quadridens (Drechsler) Subram. (1978), basionym: Triposporina quadridens Drechsler (1961)
None

Cheilodonta Boud., Bull. Trimest. Soc. Mycol. Fr. 1: 114 (1885) - Lectotype species: C. carpoboloides (P. \& H. Crouan) Boud. (1885), basionym: Peziza carpoboloides P. \& H. Crouan (1867) [ $\equiv$ Orbilia carpoboloides (P. \& H. Crouan) Baral (1994]

\section{None}

?Radotinea Velen., Monogr. Discom. Bohem.: 298 (1934) - Type species: R. caudata Velen. (1934) [(?)= Orbilia aristata (Velen.) Velen. (1947)]

?Descalsia A. Roldán \& Honrubia, Mycol. Res. 92: 494 (1989) - Type species: D. cruciata A. Roldán \& Honrubia (1989)

?Curucispora Matsush., Matsush. Mycol. Later name Mem. 2: 4 (1981) - Type species: C. ponapensis Matsush. (1981)

?Paradactylella Matsush., Matsush. Mycol. Mem. 7: 59 (1993) - Type species: P. peruviana Matsush. (1993)

Brachyphoris Juan Chen, L.L. Xu, Bin Liu \& Xing Z. Liu, Fungal Diversity 26: 128 (2007) - Type species: B. oviparasitica (G.R. Stirling \& Mankau) Juan Chen, L.L. Xu, Bin Liu \& Xing Z.Liu (2007), basionym: Dactylella oviparasitica G.R. Stirling and Mankau (1978)
Later name proposed for protection

Lecophagus M.W. Dick, Mycol. Res. 94:

L. fasciculatus M.W. Dick (1990) [=

L. muscicola (G.L. Barron et al.)

Tanabe et al. (1999)] 
Table 3 (continued)

\begin{tabular}{|c|c|c|c|}
\hline Recommended generic name & $\begin{array}{l}\text { Synonymous alternate morph generic } \\
\text { name }\end{array}$ & Additional synonymous generic names & Action required \\
\hline $\begin{array}{l}\text { Mycoceros D. Magyar \& Z. Merényi, } \\
\text { Mycol. Prog. (2017) - Type species: } \\
\text { M. antennatissimus D. Magyar (2017) }\end{array}$ & & & None \\
\hline $\begin{array}{l}\text { Orbilia Fr., Fl. Scan.: } 343 \text { (1836) - } \\
\text { Lectotype species: } O \text {. xanthostigma } \\
\text { (Fr. : Fr.) Fr. (1849) (designated by } \\
\text { Bachmann 1909), basionym: Peziza } \\
\text { xanthostigma Fr. (1815) }\end{array}$ & $\begin{array}{l}\text { Dicranidion Harkn., Bull. Calif. Acad. } \\
\text { Sci. 1: } 163 \text { (1885) - Type species: } \\
\text { Harkn. (1885) }\end{array}$ & $\begin{array}{l}\text { Pedilospora Höhn., Sitzungsber. Kaiserl. } \\
\text { Akad. Wiss. Wien, Math.-Naturwiss. } \\
\text { K1., Abt. 1, 111: } 1047 \text { [61 ofrepr.] } \\
\text { (1902) - Type species: Höhn. (1902) }\end{array}$ & $\begin{array}{l}\text { None (irrespective } \\
\text { of the generic } \\
\text { concept) }\end{array}$ \\
\hline $\begin{array}{l}\text { Pseudorbilia Ying Zhang, Z.F. Yu, Baral } \\
\text { \& K.Q. Zhang, Fungal Diversity 26: } \\
\text { 306 (2007) - Type species: P. bipolaris } \\
\text { Ying Zhang et al. (2007) }\end{array}$ & & & None \\
\hline $\begin{array}{l}\text { Pseudotripoconidium Z.F. Yu \& K.Q. } \\
\text { Zhang, in Yu et al., Mycologia 103(1): } \\
168 \text { (2011) - Type species: P. sinense } \\
\text { Z.F. Yu \& K.Q. Zhang (2011) (use } \\
\text { when applying a narrow generic } \\
\text { concept, otherwise use Helicoon, } \\
\text { Habrostictis, or Orbilia) }\end{array}$ & & & None \\
\hline $\begin{array}{l}\text { Retiarius D.L. Olivier, Trans. Br. Mycol. } \\
\text { Soc. 71: } 194 \text { (1978) - Type species: } \\
\text { R. superficiaris D.L. Olivier (1978) }\end{array}$ & & & None \\
\hline $\begin{array}{l}\text { Vermispora Deighton \& Piroz., Mycol. } \\
\text { Pap. 128: } 87 \text { (1972) - Type species: } \\
\text { V. grandispora Deighton \& Piroz. } \\
\text { (1972) }\end{array}$ & & $\begin{array}{l}\text { ?Microdochiella Hern.-Restr. \& Crous, } \\
\text { Persoonia 36: } 62 \text { (2015) - Type } \\
\text { species: M. fusarioides (D.C. Harris) } \\
\text { Hern.-Restr. \& Crous (2015), } \\
\text { basionym: Microdochium fusarioides } \\
\text { D.C. Harris (1985) }\end{array}$ & None \\
\hline
\end{tabular}

Recommended names are listed in bold in the first column, the second column indicates the oldest competing alternate morph generic name, and the third column in chronological order any further synonymous generic names. The last column indicates the action required, such as protection of sexual morph names without priority or asexual morph names that need protection

continuously been applied over the centuries, but Arthrobotrys was mainly used for nematode-trapping species, which represent a comparatively small group within the Orbiliomycetes. When using a moderate generic concept, Arthrobotrys should be used for the group that comprises all nematode-trapping fungi included in the series Arthrobotrys, Dactylellina, Drechslerella, and Gamsylella, because it is the oldest of these generic names, and also because of its large species number. Such a concept should, however, also include non-predacious species currently recognized in Dactylella p.p. (see there and Fig. 1: section Arthrobotrys). Under a narrow generic concept, all these asexual morph names are recognized as distinct holomorph genera, because they delineate well-defined phylogenetic but also morphologically distinct groups in regard to their trapping organs (but see under these names for competing sexually typified genera).
Brachyphoris Juan Chen, L.L. Xu, Bin Liu \& Xing Z. Liu (2007) - Use the older name Hyalorbilia (S) instead of Brachyphoris (A).

Brachyphoris was erected by Chen et al. (2007a, c) for five species previously assigned to Dactylella (with B. oviparasitica as the type species) but having shorter conidiophores and a considerable molecular distance to other Dactylella species. Two of the five species (B. helminthodes and B. stenomeces) lack DNA sequences and were assigned to the genus merely on the basis of short conidiophores. It is uncertain, however, whether these two species are related to Brachyphoris because such short conidiophores are frequently observed in various groups of desiccation-tolerant species of Orbilia s. 1 .

Brachyphoris is a synonym of the sexually typified genus Hyalorbilia (Fig. 2c-e), and was established to 
accommodate the asexual morphs of that genus (Fig. 4a, b). Although no DNA sequence of the type species $H$. berberidis is available, there is little doubt about its close relationship to $B$. oviparasitica. That species is only known from the asexual morph, but it is phylogenetically closely related to $H$. brevistipitata $\mathrm{B}$. Liu et al. with its asexual morph $B$. brevistipitata (B. Liu et al.) Juan Chen et al. Many of the asexual morphs observed by us in Hyalorbilia have very similar fusoid, brachyphoris-like conidia, for which an example is shown in Fig. 4a. Also, 'Dactylella' passalopaga, a species that captures testaceous rhizopods (Fig. 5c), has such conidia and is undoubtedly a member of Hyalorbilia.

Brachyphoris and Hyalorbilia are competing names and only one of them should now be used. We give preference to the older name Hyalorbilia, with ten validly described species, rather than Brachyphoris, with only five species. Two new combinations are proposed here for species without a known sexual morph:

Hyalorbilia oviparasitica (G.R. Stirling \& Mankau) E. Weber \& Baral, comb. nov.

MycoBank MB 813456

Basionym: Dactylella oviparasitica G.R. Stirling \& Mankau, Mycologia 70(4): 777 (1978).

$\equiv$ Brachyphoris oviparasitica (G.R. Stirling \& Mankau) Juan Chen, L.L. Xu, B. Liu \& Xing Z. Liu, Fungal Diversity 26(1): 79 (2007).

Hyalorbilia tenuifusaria (Xing Z. Liu, R.H. Gao, K.Q. Zhang \& L. Gao) E. Weber \& Baral, comb. nov.

MycoBank MB 813463

Basionym: Dactylella tenuifusaria Xing Z. Liu, R.H. Gao, K.Q. Zhang \& L. Cao, Mycol. Res. 100(2): 236 (1996).

三Brachyphoris tenuifusaria (Xing Z. Liu, R.H. Gao, K.Q. Zhang \& L. Gao) Juan Chen, L.L. Xu, Bin Liu \& Xing Z. Liu, Fungal Diversity 26(1): 124 (2007).

Candelabrella Rifai \& R.C. Cooke (1966) - Use the older name Arthrobotrys (A) instead of Candelabrella (A) when applying a narrow or moderate generic concept, otherwise use Orbilia (S).

Candelabrella with the type species C. javanica was proposed for two species with 1-septate conidia and adhesive networks capturing nematodes. It was segregated from Arthrobotrys because of its candelabrum-like (candelabrelloid) conidiophore tips. Eight further species have later been included in the genus (Index Fungorum), with mainly adhesive networks, but also with adhesive knobs, the trapping organ of Dactylellina. Since Scholler et al. (1999), the synonymy with Arthrobotrys has been generally recognized.
Cheilodonta Boud. (1885) - Use the older name Habrostictis (S) instead of Cheilodonta (S) when applying a moderate or narrow generic concept, otherwise use Orbilia (S).

Cheilodonta was proposed for two species, C. carpoboloides and $C$. lasia, based on apothecia with a dentate margin and acuminate-spathulate paraphysis tips. Boudier (1907) transferred both taxa to Habrostictis as the older generic name. $C$. carpoboloides was later designated as lectotype. C. lasia was early found to be a synonym of $H$. rubra, the type of Habrostictis, which in turn was synonymised with Orbilia carpoboloides by Baral (1994).

Curucispora Matsush. (1981) - Protect Hyalorbilia (S) over the older Curucispora (A) in case of congenericity.

Curucispora was erected with one species, $C$. ponapensis. Two further species have later been included. The name Cruciconidiifera, proposed by Matsushima (2005) to replace Crucispora (the originally intended spelling) because of homonymy with Crucispora Horak, was possibly invalid in case that hard copies have not been provided. The name Curucispora should be maintained because Matsushima did not correct his error in a corrigendum of the 1981 volume and because the correction affects the first syllable of the generic name (Art. 60.3 ICN).

The tetraradiate conidia of Curucispora deviate from those of the similar Descalsia in showing two central cells divided by an oblique septum. They also differ in conidial shape, with the arm initials appearing V-shaped in the center of a bent axis, and later elongating to form a tetraradiate three-dimensional structure. In Descalsia, in contrast, the arms arise oppositely in the middle of the elongate straight main axis, and the conidia are said to be typically planar (cross-shaped). However, conidia with an obliquely septate central cell also sometimes occurred in Descalsia cruciata, and, in our strains tentatively referred to as descalsia-like (Fig. 3z), the arms show a threedimensional orientation, but in preparations with a cover slip, they are forced to lie in one plane and can be easily mistaken as planar. Also, Descals (pers. comm.) recalls having observed some conidia in D. cruciata in which two of the four branches form an acute angle ("V"), which might indicate that they had a three-dimensional orientation.

Molecular data are lacking, and the holotype of C. ponapensis was preserved only as a dried culture. The type species resembles in conidial morphology an asexual morph which was observed in association with an undescribed species of Hyalorbilia similar to H. fusispora (Baral et al., unpubl., Fig. 3y); therefore, $C$. ponapensis might be the asexual morph of a Hyalorbilia (but Fig. 3y also shows a similarity to Retiarius superficiaris). Curucispora flabelliformis K. Ando differs by curved arms and closely resembles an asexual 

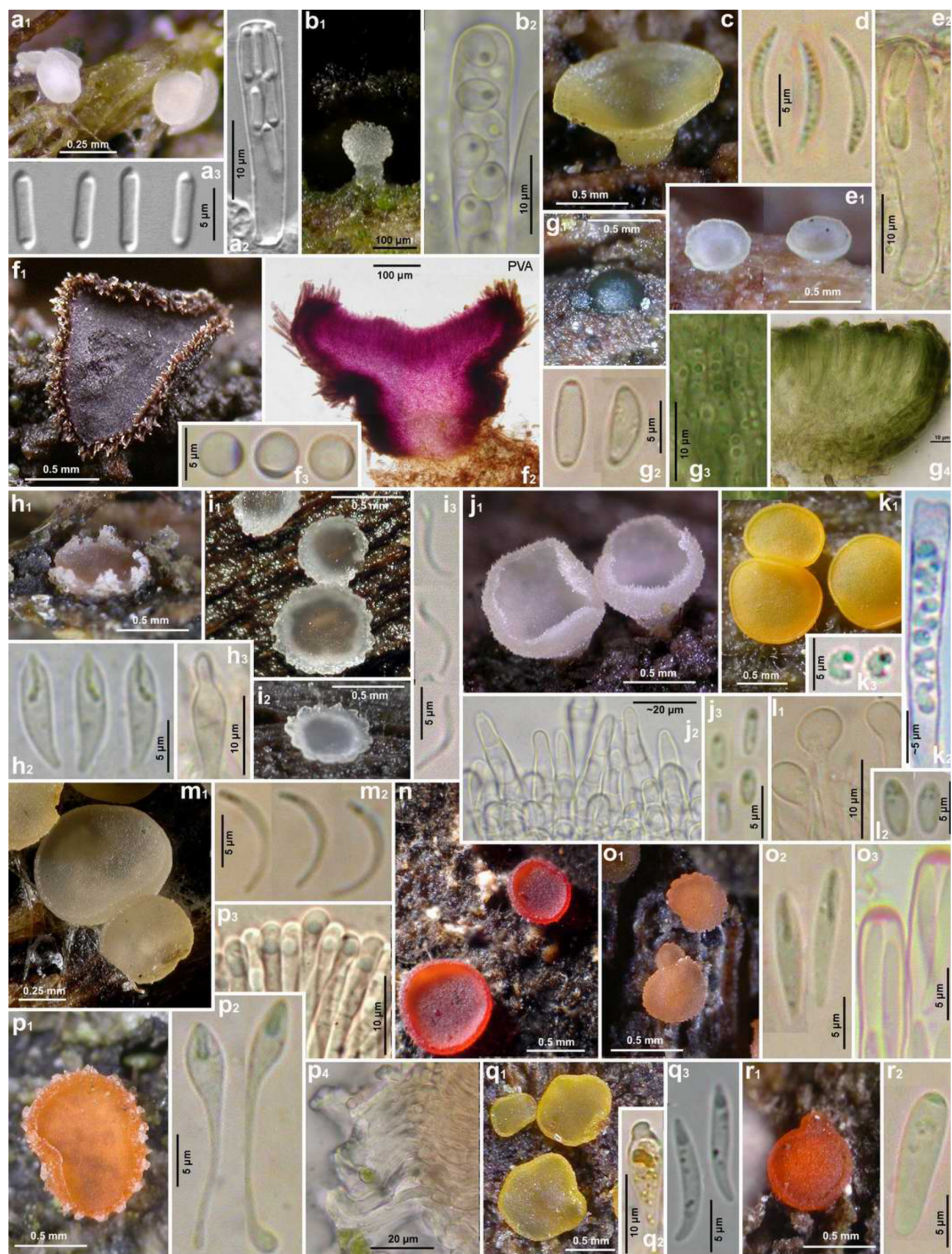
Fig. 2 Sexual morphs of Orbiliomycetes $\left(a_{3}, b_{2}, d, f_{3}, g_{2}, h_{2}, i_{3}, j_{3}, k_{3}, l_{2}\right.$, $\mathrm{m}_{2}, \mathrm{o}_{2}, \mathrm{p}_{2}, \mathrm{q}_{3}, \mathrm{r}_{2}$ : ascospores with spore bodies; $\mathrm{a}_{2}, \mathrm{~b}_{2}, \mathrm{e}_{2}, \mathrm{k}_{2}, \mathrm{o}_{3}:$ asci; $\mathrm{h}_{3}$, $\mathrm{l}_{1}, \mathrm{p}_{3}, \mathrm{q}_{2}$ : paraphyses; $\mathrm{g}_{3}, \mathrm{j}_{2}$ : hairs; $\mathrm{p}_{4}$ : glassy processes): a Pseudorbilia bipolaris (from Zhang et al. 2007, H.B. 8794); b Lecophagus 'ellipsoideus' ined. (16.XI.2013); c Hyalorbilia inflatula (TAAM 63888), d H. berberidis (H.B. 8605a); e H. polypori (H.B. 9361, 7943b); f 'Lilapila oculisporella' ined. (H.B. 7063a, 4822, 9162a); g 'Amphosoma atroolivaceum' ined. (H.B. 9143b, 9136c, 8057); h Orbilia carpoboloides (section Habrostictis, H.B. 9083a, 13.VI.2009, 9233); i O. crenatomarginata (sect. 'Aurantiorubrae', H.B. 7683, 9304, P.P. 20070827); j O. pilosa (series Drechslerella, type of Orbiliaster, H.B. 9437); k O. xanthostigma (sect. Orbilia, 16.VI.2007, 3.VII.2006, 21.X.2010); I O. eucalypti (sect. Orbilia, H.B. 8427, H.B. 9226f); m O. auricolor (series Arthrobotrys, 8.I.2011, H.B. 8898a); n $O$. 'rubrovacuolata' ined. (series Dactylellina, H.B. 7719a); о O. vinosa (sect. Hemiorbilia, H.B. 5518, 7861a, 7249c, 18.II.2010); p O. 'subaristata' ined. (sect. Hemiorbilia, H.B. 9163b, 9151d, 10.II.2014); q O. xanthoguttulata (sect. 'Aurantiorubrae', H.B. 8170a, 17.III.2011); r O. 'lentiformis' ined. (sect. 'Lentiformes', H.B. 9578a, 7891b). Living state, except for ascus in $\mathrm{k}_{2}$ (in water) and asci and spores in $\mathrm{o}_{3}$ (in Congo red)

morph obtained in pure culture of an unnamed Hyalorbilia (Fig. 3x, Baral et al., unpubl.).

If DNA can be extracted from the dried type culture of C. ponapensis and it is demonstrated that this species falls within Hyalorbilia, then Hyalorbilia should be protected over Curucispora in order to avoid a much greater number of name changes.

Dactylariopsis Mekht. (1967) — Use the older name Drechslerella (A) instead of Dactylariopsis (A) when applying a narrow generic concept, otherwise use Arthrobotrys (A) or Orbilia (S).

Dactylariopsis, with the type species D. brochopaga, was segregated from Dactylella and Dactylaria by the capability of capturing nematodes, from Dactylella also by apically at least partly denticulate conidiophores. Mekhtieva (1967) included six species that either form constricting rings (including $D$. brochopaga), adhesive knobs, or adhesive networks. Scholler et al. (1999) placed Dactylariopsis in synonymy with Drechslerella.

Dactylella Grove (1884) — Use Dactylella (A) when applying a narrow generic concept (epitypification of $D$. minuta required), otherwise use Arthrobotrys (A) or Orbilia (S).

Dactylella was erected with one species, D. minuta, which was described with long unbranched conidiophores with a single terminal phragmoconidium. The holotype of $D$. minuta is located in $\mathrm{K}$ but consists of a piece of dead wood without any trace of the fungus (Rubner 1996). However, there is an illustration of D. minuta (Grove 1884: tab. 246, fig. 6) which can serve as part of the holotype (Art. 8.1. ICN). A culture was probably not made by Grove, and further unambiguous records are unknown.

The circumscription of Dactylella has been emended several times by various authors by including also species with apically branched conidiophores. It was Rubner (1996) who restricted the genus to non-nematophagous species. Chen et al. (2007a, b) found that Dactylella was still heterogeneous with species in three distinct clades: Brachyphoris (sexual morph Hyalorbilia), Vermispora (sexual morph unknown), and Dactylella (sexual morph Orbilia). Under this generic concept, Drechsleromyces and Gangliophragma are synonyms of Dactylella.

A total of 106 specific epithets have been combined in Dactylella (Index Fungorum). Chen et al. (2007a) accepted 28 species in Dactylella s. str., which are saprotrophic though partly capable of invading oospores or nematode eggs. Various molecular phylogenetic studies including the present one (Fig. 1) showed that the available sequences of Dactylella in this restricted concept form a paraphyletic group in close vicinity of the nematode-trapping genera Arthrobotrys, Dactylellina, Gamsylella, and Drechslerella. Its paraphyly and frequently basal placement suggest that Dactylella represents the ancestor of the four nematophagous genera.

Dactylella-like asexual morphs were observed by us in three different groups of Orbilia s. 1. (Fig. 1): series Dactylella (Fig. 4e-g), section 'Aurantiorubrae' (two clades, Fig. 4c, see under Hyalinia), and series Orbilia (Fig. 4d), apart from the dactylella-like asexual morph of Hyalorbilia (Brachyphoris, Fig. 4a, b).

The morphological similarity of some asexual morphs referable to Dactylella in a wide sense but belonging to different clades is remarkably high; therefore, it remains unclear to which of these clades the type species $D$. minuta belongs. From its morphology, we suspect that it could either be the asexual morph of a member of series Dactylella (e.g., Orbilia cardui Velen.) or of $O$. crenatomarginata (section 'Aurantiorubrae' ined.). When applying a narrow generic concept, the generic name Dactylella needs to be fixed by designating an epitype for D. minuta in accordance with Chen et al.'s (2007a) concept of Dactylella. However, no taxon or specimen that matches the large conidial size given by Grove (1884) is known to us. CBS cultures deposited under the name D. minuta by W. Gams and re-identified as D. rhopalota by Rubner (1996) have conidia of a size much smaller than that described by Grove.

Dactylellina M. Morelet (1968) — Use Dactylellina (A) when applying a narrow generic concept, otherwise use Arthrobotrys (A) or Orbilia (S).

Dactylellina was erected with one species, D. leptospora, which was proposed as a replacement name for Dactylosporium. The genus was emended by Scholler et al. (1999) to comprise all those 17 species known at that time that trap nematodes by means of adhesive knobs or, in some species, additionally by non-constricting rings (Fig. $5 \mathrm{~d}$, e). Various further species were later added, partly by including the genus Gamsylella, so that, at present, 31 specific epithets have been combined in Dactylellina (Index Fungorum). The 


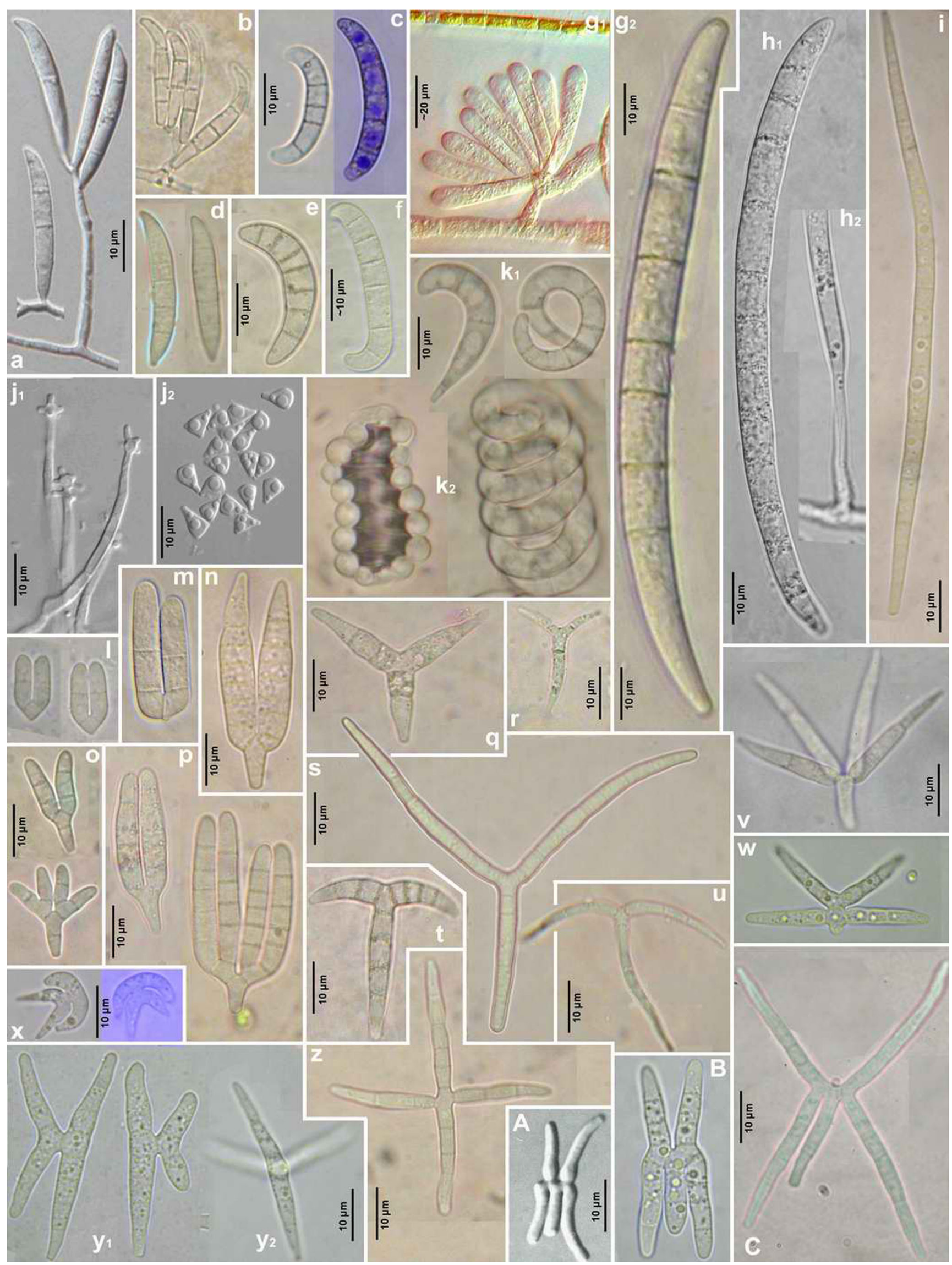


Fig. 3 Conidiophores and conidia of Orbiliomycetes with curved, inversely pyramidal, or stauroconidia (non-predacious taxa except for Lecophagus). Vermispora: a V. fusarina (from Chen et al. 2007c); vermispora-like: b Orbilia 'brachychitonis' ined. (sect. 'Aurantiorubrae', H.B. $7578 \mathrm{a}$ ); c O. aurantiorubra (sect. 'Aurantiorubrae', 4.I.2013, 3.IV.2013); d O. 'pleistoeuonymi' ined. (sect. 'Lentiformes', H.B. 9237a); e O. 'patellarioides' ined. (sect. 'Lentiformes', H.B. 9173h); f O. 'aradi' ined. (sect. 'Aurantiorubrae', H.B. 7884); Lecophagus: g L. muscicola (H.B. 7771); anguillosporalike: h O. yuanensis (sect. Helicoon, from Qiao et al. 2015); i $O$. 'caulicola' ined. (sect. 'Aurantiorubrae', G.M. 2013-07-30); Pseudotripoconidium: j O. sinensis (sect. Helicoon, from Yu et al. 2011); Helicoon: k O. luteorubella (sect. Helicoon, H.B. 9424a); dicranidion-like: I O. eucalypti (sect. Orbilia, 10.IV.2013); m O. xanthoguttulata (sect. 'Aurantiorubrae', H.B. 7884b); n O. 'ovalis' ined. (presumed, sect. 'Lentiformes', H.B. 7156a); o O. fissilis (sect. Orbilia, H.B. 7566a); p O. abutilonis (sect. 'Aurantiorubrae', H.B. 8546); trinacrium-like: q $O$. 'obtusispora' ined. (sect. Habrostictis, H.B. 8144); r Hyalorbilia erythrostigma (H.B. 6209a); s $O$. 'clavuliformis' ined. (sect. Hemiorbilia, 28.III.2009); t O. pilifera (sect. 'Aurantiorubrae', H.B. 8076a); u 'Amphosoma resinicola' ined. (H.B. 6992a); tridentaria-like: v O. septispora (sect. Habrostictis, H.B. 7267a); unnamed: w O. 'multimicrosoma' ined. (sect. Orbilia, 7.V.2004); curucispora-like: $\mathbf{x}$ Hyalorbilia 'latispora' ined. (H.B. 9902c); y H. 'subfusispora' ined. (8.XII.2009); descalsia-like: $\mathbf{z}$ 'O. flagellispora' comb. ined. (H.B. 8264); dwayaangam-like: A O. junci (from Kohlmeyer et al. 1998); B O. 'subvinosa' ined. (H.B. 9173b); C O. aristata (7.V.2004, z, A-C sect. Hemiorbilia). Living state (c and $x$ partly in Cresyl blue), except for $\mathrm{t}$ (in water) and $\mathrm{u}$ (in $\mathrm{KOH}$ )

conidia are often fusiform (Fig. 4h, i). Bright red apothecia are characteristic of Orbilia 'rubrovacuolata' ined. (Fig. 2n), which has an asexual morph very similar to $D$. mammillata (S.M. Dixon) M. Scholler et al. In our phylogenetic analysis, the genus is represented as series Dactylellina (Fig. 1).

Scholler et al.'s concept resulted in the synonymy of Laridospora and Kafiaddinia with Dactylellina. The type species of the older genus Anulosporium is of doubtful identity (see there). Therefore, we propose to protect the name Dactylellina in case the narrow generic concept is applied.

Dactylium Nees (1816) - Use Dactylellina (A) instead of the rejected name Dactylium (A) when applying a narrow generic concept, otherwise use Arthrobotrys (A) or Orbilia (S).

The type species $D$. candidum is of unclear identity based on its original description. Drechsler (1937a: 523) applied the taxon as Dactylaria candida (Nees) Sacc. to an isolate that forms long-stalked adhesive knobs and non-constricting rings, which, according to Rubner (1996: 74), might belong to Monacrosporium haptotylum (Drechsler) X.Z. Liu \& K.Q. Zhang, a species now classified in Dactylellina. Gams and Rubner (1997) proposed to reject the names Dactylium and $D$. candidum in order to retain the generic name Monacrosporium in case Drechsler's redescription would be accepted as a neotypification of $D$. candidum (Rubner 1996: 37). Index Fungorum lists a total of 46 names, many of which belong to other classes.

\section{Dactylosporium Mekht. (1967) — see under Kafiaddinia} (A).

This illegitimate name is a homonym of Dactylosporium Harz (hyphomycetes inc. sedis). It was proposed for D. leptospora as a segregate of Dactylella based on its nematophagy by means of stalked adhesive knobs and nonconstricting rings, and often apically branched, denticulate conidiophores. Because of its illegitimacy, it was later replaced by Dactylellina (see also under Kafiaddinia).

Descalsia A. Roldán \& Honrubia (1989) - Use Hemiorbilia (S) (existing at present only at the infrageneric level). Raise Hemiorbilia to genus to be used rather than the unclear Descalsia (A) when applying a moderate or narrow generic concept.

This genus only includes Descalsia cruciata, which has tetraradiate stauroconidia similar to Fig. $3 \mathrm{z}$ or in Curucispora (see there). There is a possibility that $D$. cruciata belongs to the core of Orbilia subgenus Hemiorbilia, but, at present, it cannot be connected with certainty to a sexual morph and even its relationship with Orbiliomycetes is not certain. Orbilia aristata (Velen.) Velen., a close relative of $O$. occulta (type of subgenus Hemiorbilia), forms tetraradiate conidia very similar to D. cruciata in pure culture. However, we have also often observed trinacrium- (Fig. 3s) and dwayaangam-like (Fig. 3C) conidia with very similar arm dimensions close to the apothecia of $O$. aristata on the natural substrate, partly also in ascospore isolates of this species, and these three conidial types were also observed in connection with $O$. 'subaristata' (ined.) and O. flagellispora (comb. ined.).

Because of the uncertain identity of $D$. cruciata, Descalsia cannot now be used as a holomorph-generic name. No living ex-type culture or sequence exists (A. Roldán \& L. Marvanová, pers. comm.), and efforts by G. Marson to gain DNA from a permanent slide failed. In case $D$. cruciata would turn out to be closely related to $O$. occulta, the name Descalsia could be used instead of raising subgenus Hemiorbilia to the generic level. However, Curucispora might represent an older name. As long as the phylogenetic relationship remains unclear, we suggest not to use Descalsia.

\section{Dicranidion Harkn. (1885) — Use the older name Orbilia} (S) instead of Dicranidion (A).

Dicranidion was erected with one species, D. fragile, and 12 further specific epithets were later associated with it (Index Fungorum). The name of the genus refers to the shape of conidia resembling a tuning fork (from Greek dikranos). Such conidia were found by us to occur in several groups of Orbilia (see Fig. 1). They differ in arm and stipe length, and in the number of arms (Fig. 31-p). The type species clearly fits the asexual morph obtained from ascospore isolates of the common, worldwide O. eucalypti (W. Phillips \& Harkn.) Sacc. (= O. alnea Velen., Baral et al., unpubl.), which belongs to section Orbilia. 


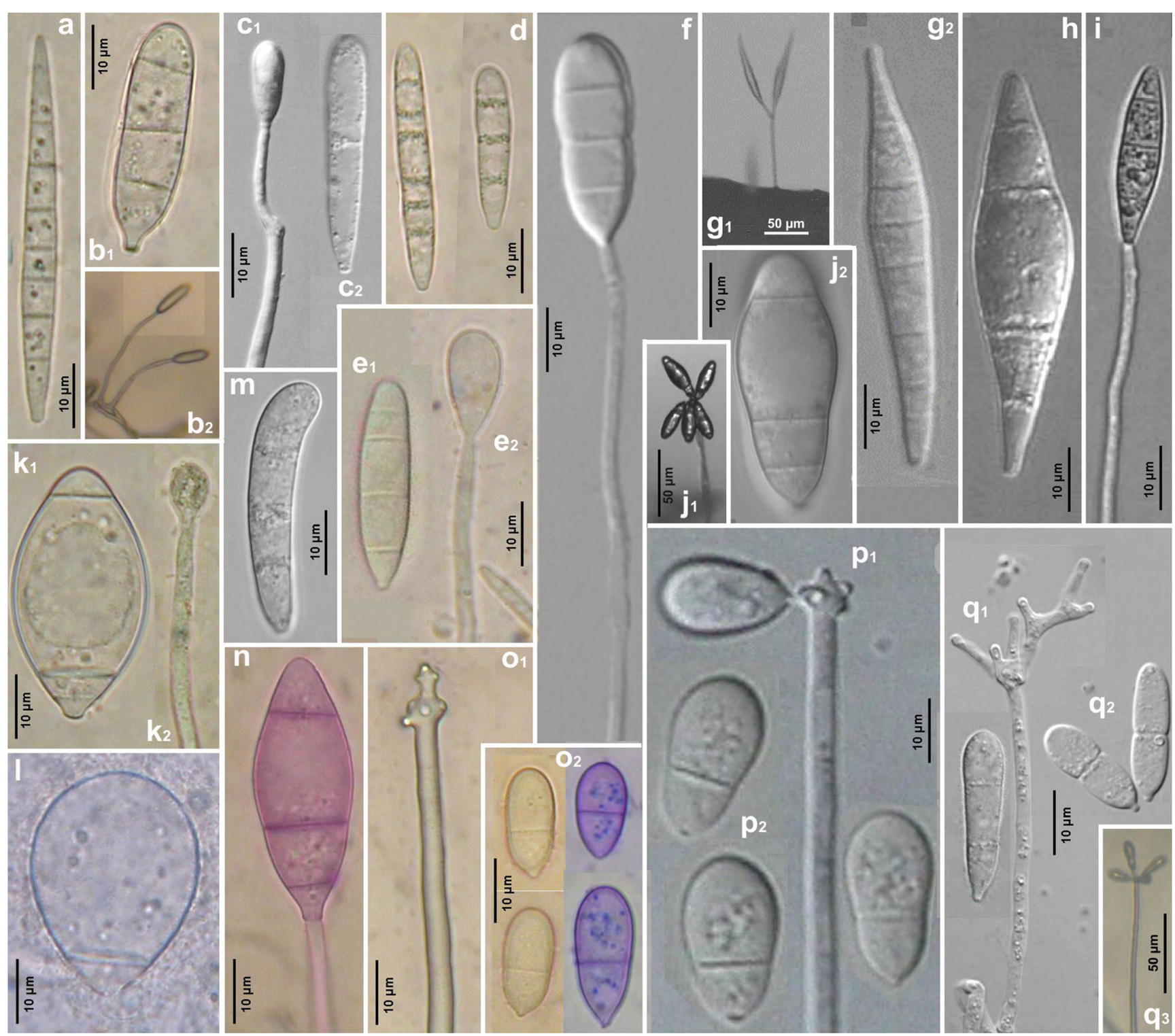

Fig. 4 Conidiophores and conidia of Orbiliomycetes with unbranched, mainly uncurved conidia, mainly predacious taxa (except for dactylellalike taxa): Hyalorbilia (= Brachyphoris): a H. inflatula (H.B. 9041a); b H. polypori ( $\mathrm{b}_{1}$ H.B. $7952 \mathrm{a}, \mathrm{b}_{2}$ H.B. $\left.7557 \mathrm{a}\right)$; dactylella-like: c Orbilia vermiformis (sect. 'Aurantiorubrae', from Yu et al. 2007a); d O. dryadum (sect. Orbilia, H.B. 8224a). Series Dactylella: e D. clavispora (H.B. 8371a); f D. clavispora (from Chen et al. 2007b); g O. dorsalis (from Yu et al. 2007b). Series Arthrobotrys: j O. blumenaviensis (=

Due to the scattered occurrence of dicranidion-like asexual morphs within Orbilia s. 1. and the widely accepted name Orbilia, we dismiss the name Dicranidion and recommend to use Orbilia no matter which generic concept is adopted. Some connections between Dicranidion species and sexual morphs within the series Orbilia are uncertain due to the lack of molecular data. For instance, D. gracile Matsush. or $D$. tenue Matsush. fit the asexual morphs of $O$. leucostigma (Fr. : Fr.) Fr. and $O$. xanthostigma, but the ex-type strains appear to have never been subjected to DNA sequencing. In
A. vermicola, from Qiao et al. 2012); n A. elegans (H.B. 6972a); o O. auricolor (H.B. 8898a, 9553); p A. oligospora (from Swe et al. 2008). Series Drechslerella: k D. cf. bembicodes (H.B. 9051g); l D. polybrocha (H.B. 8317a); m O. cf. orientalis (= D. brochopaga agg., YMF 1.01854, from Z.F. Yu et al., unpubl.). Series Dactylellina: h $D$. sichuanensis (from Li et al. 2006); i D. varietas (from Li et al. 2006). Series Gamsylella: q O. alba ( $\mathrm{q}_{1-2}$ from Yu et al. 2009, $\mathrm{q}_{3}$ H.B. 9645a). Living state ( $\mathrm{n}$ and $\mathrm{O}_{2}$ in Cresyl blue)

the following taxon, we could confirm the connection to a sexual morph by molecular data gained from an ascospore isolate that formed the typical conidia (GenBank number of the ex-type culture: LC146730, our strain: KT596781):

Orbilia fissilis (K. Ando \& Tubaki) E. Weber \& Baral, comb. nov. (Fig. 3o)

MycoBank MB 813955

Basionym: Dicranidion fissile K. Ando \& Tubaki, Trans. Mycol. Soc. Japan 25(1): 39 (1984). 
Didymozoophaga Soprunov \& Galiulina (1951) — Use Arthrobotrys (A) instead of the invalid and illegitimate Didymozoophaga (A).

Didymozoophaga was proposed to include nine species and some varieties that have 1-septate conidia formed on arthrobotryoid conidiophores and trap nematodes by means of adhesive networks. No type species was designated by the authors. Later, Soprunov (1958) placed the genus in synonymy with Arthrobotrys. The name Didymozoophaga is invalid because no Latin diagnosis was given (Art. 39 ICN). Schenck et al. (1977) designated D. oligospora as the lectotype species, but, later, van Oorschot (1985) selected D. superba as the lectotype, obviously overlooking the lectotypification by Schenck et al. We consider the lectotypification by van Oorschot, which would make Didymozoophaga illegitimate (Art. 52 ICN), as superfluous.
Drechslerella Subram. (1964) - Protect Drechslerella (A) over the older Orbiliaster (S) when applying a narrow generic concept, otherwise use Arthrobotrys (A) or Orbilia (S).

Drechslerella was erected with one species, D. acrochaeta, based on fusiform conidia with a long, filiform apical appendage. The genus was redefined by Scholler et al. (1999) to include 13 species that trap nematodes by means of constricting rings (Fig. 5h, i). At present, it comprises 15 species (Index Fungorum). This concept resulted in the synonymy of Golovinia and Dactylariopsis with Drechslerella. The conidia vary between fusiform, obovoid, and cylindrical (Fig. $4 \mathrm{k}-\mathrm{m}$ ). When applying a narrow generic concept, Drechslerella should be adopted as a holomorph name (in Fig. 1, as series Drechslerella).

However, the genus Orbiliaster was found to provide an older name for this group (see below). Drechslerella has been
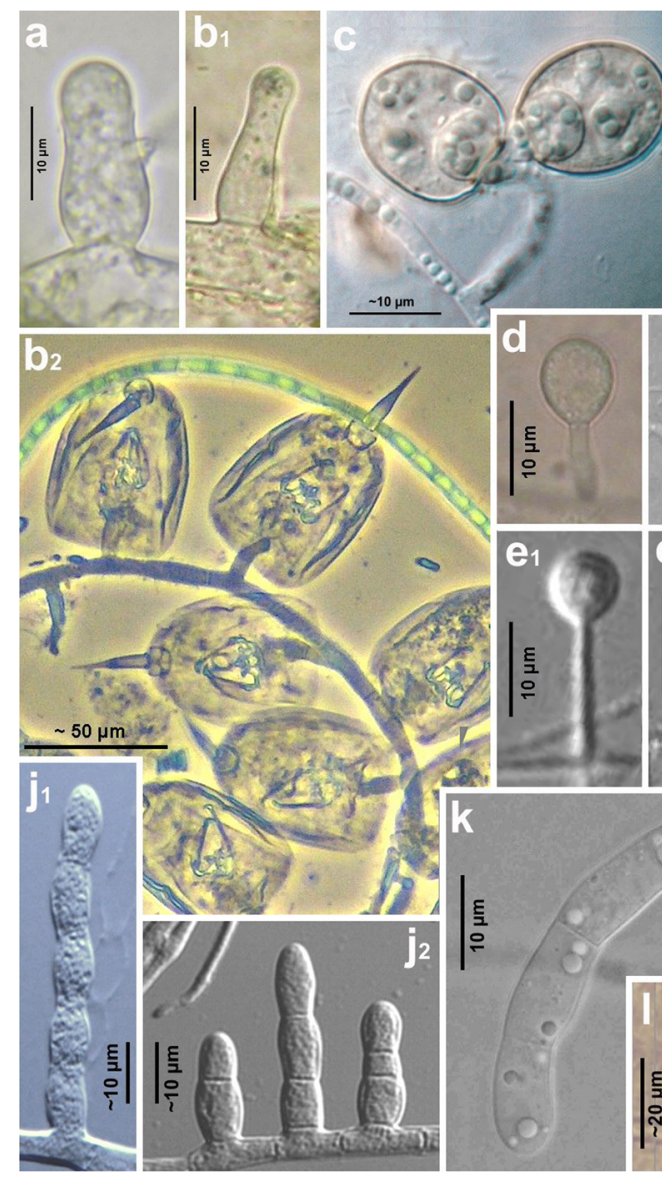

Fig. 5 Trapping organs in Orbiliomycetes. Lecophagus: adhesive pegs capturing rotifers: a L. 'ellipsoideus' ined. (16.XI.2013); b L. muscicola (H.B. 7771). Hyalorbilia (= Brachyphoris): adhesive pegs capturing testaceous rhizopods: c Hyalorbilia sp. (as Dactylella passalopaga, from G. Barron, website on fungi). Series Dactylellina: adhesive knobs and non-constricting rings capturing nematodes: d D. mammillata (H.B. 8372a); e D. sichuanensis (from Li et al. 2006). Series Arthrobotrys: adhesive network capturing nematodes: f Orbilia blumenavensis (= A. vermicola, from Qiao et al. 2012). Series Gamsylella: adhesive

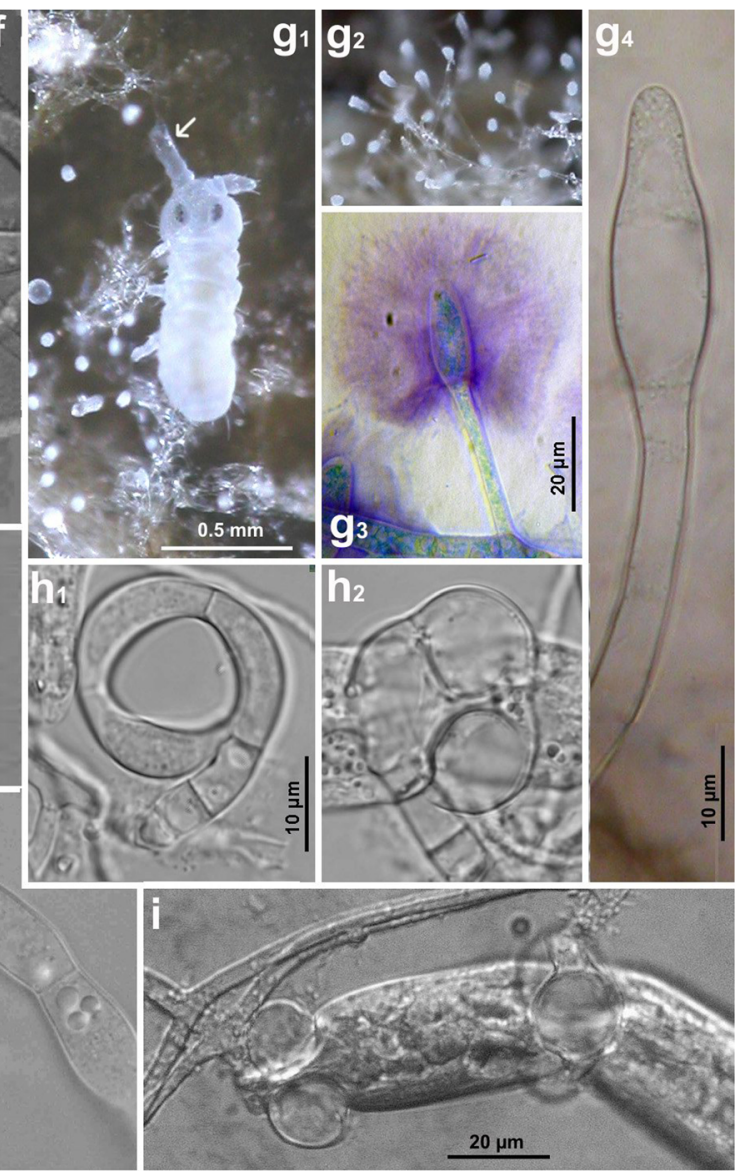

knobs with thick gel capturing arthropods: g O. alba (H.B. 9645a, 9051a); adhesive columns and bridges: j, I G. cf. cionopaga (XJ03, from X.Z. Liu et al. unpubl.); k G. cionopaga (from Z.F. Yu unpubl.). Series Drechslerella: constricting rings capturing nematodes: $\mathbf{h} O$. cf. orientalis (= D. brochopaga agg., YMF 1.01854, from Z.F. Yu et al. unpubl.); i D. doedycoides, captured nematode (from H.Y. Su unpubl.). Living state, except for $b_{2}$, ?e, g [methyl-green in ammonium hydroxide, post-stained by cresyl blue (when hydrated, the gel sheath requires staining for a better visibility)], $\mathrm{j}$ 
widely used since its emendation and, at present, comprises 15 accepted species, whereas only two species were recognized in Orbiliaster. Therefore, we recommend protection of Drechslerella over Orbiliaster when applying a narrow generic concept.

Drechsleromyces Subram. (1978) — Use the older name Dactylella (A) instead of Drechsleromyces (A) in case of congenericity when applying a narrow generic concept, otherwise use Arthrobotrys (A) or Orbilia (S).

Drechsleromyces was erected with one species, D. atractoides, which was segregated from Dactylella because of sympodially proliferating conidiophores and from Gangliophragma by the constriction between denticle and conidium (narrow attachment). No other epithet was combined in the genus. It was considered a synonym of Dactylella by Chen et al. (2007b), based on molecular data.

Duddingtonia R.C. Cooke (1969) — Use the older name Arthrobotrys (A) instead of Duddingtonia (A) when applying a moderate or narrow generic concept, otherwise use Orbilia (S).

Duddingtonia was erected with one species, D. flagrans, which was segregated from Arthrobotrys based on the absence of nodules at the conidiophore tips. No further epithet has been combined in the genus, and its type species was accepted in Arthrobotrys by Scholler et al. (1999) because it forms adhesive networks and clusters in that genus (see Fig. 1).

\section{Dwayaangam Subram. (1978) — Protect Hyalorbilia (S)} over Dwayaangam (A).

The genus was introduced for one species, D. quadridens, with short conidiophores giving rise to normally four-armed stauroconidia formed by repeated dichotomous branching (the name is derived from Sanskrit: $d w a y a=$ two, angam $=$ branch). No ex-type culture seems to exist, and no type specimen could be located.

Eight species have been recognized, one representing the asexual morph of Orbilia junci Kohlm., Baral \& Volkm.-Kohlm. Out of these, sequence data are only available for $D$. colodena, which, in phylogenetic analyses, clusters in the Helotiales near Arachnopeziza. Considering that the conidia of $D$. colodena show a somewhat irregular mode of branching, with usually six arms, all the other species of the genus may well belong to the Orbiliomycetes. Studies of Baral et al. (unpubl.) revealed some unidentified Dwayaangam asexual morphs, especially in section Hemiorbilia, but also in species around $O$. 'albovinosa' (ined.) of section 'Aurantiorubrae' and Hyalorbilia fusispora (Velen.) Baral \& G. Marson (Figs. 1 and $3 \mathrm{~A}-\mathrm{C}$ ), which more or less closely resemble some of the described Dwayaangam species, although we cannot unambiguously name them.

The original illustration of $D$. quadridens hardly leaves any doubt about its relationship to the Orbiliomycetes. The drops in the broad cells of the living conidia as drawn by Drechsler are probably of non-lipidic nature and point to a relationship with Hyalorbilia, in which such drops, in contrast to Orbilia s. 1., have frequently been observed, and branched conidia occur in some species. This hypothesis is supported by Drechsler's observation that D. quadridens is predacious on rhizopods, which is also known from 'Dactylella' passalopaga. The latter asexual morph undoubtedly belongs to Hyalorbilia, but cannot be unequivocally assigned to a sexual morph species because very similar conidia occur in various species of that genus, including $H$. inflatula (P. Karst.) Baral \& G. Marson (Baral et al., unpubl.).

Based on the above data, the asexual morph name Dwayaangam competes with the sexual morph name Hyalorbilia. We recommend protection of the younger Hyalorbilia, in which, until now, ten species have been combined, instead of Dwayaangam, with only one species for which an affinity to Hyalorbilia is highly probable. As a consequence, this species is here combined into Hyalorbilia:

Hyalorbilia quadridens (Drechsler) Baral \& E. Weber, comb. nov.

MycoBank MB 813462

Basionym: Triposporina quadridens Drechsler, Sydowia 15(1-6): 19 (1962) [“1961”]

三Dwayaangam quadridens (Drechsler) Subram.

Gamsylella M. Scholler, Hagedorn \& A. Rubner (1999) Use Gamsylella (A) when applying a narrow generic concept, otherwise use Arthrobotrys (A) or Orbilia (S).

Gamsylella with the type species G. arcuata was erected to accommodate six species that trap nematodes by means of unstalked adhesive knobs or two- to multicelled columns, which tend to form arches or scalariform bridges (Fig. 5j-1). A seventh species (G. cionopaga) was later invalidly combined. The conidia vary between cylindrical and fusiform. When applying a narrow generic concept, the name Gamsylella could be adopted as a holomorph generic name. However, delimitation from Dactylellina proved to be difficult, and some authors concluded that both genera should be merged. In our phylogenetic analysis, the two genera are separated as sister clades, though with low support (Fig. 1). Sexual morphs are unknown at present in Gamsylella, except for unpublished results on two further species that cluster with Gamsylella. One of them, Orbilia alba Dennis, forms large, stalked, elongate adhesive knobs which trap arthropods such as collembolans or dipterans (Figs. 4q and 5g). 
Gangliophragma Subram. (1978) — Use the older name Dactylella (A) instead of Gangliophragma (A) in case of congenericity when applying a narrow generic concept, otherwise use Arthrobotrys (A) or Orbilia (S).

Gangliophragma with the type species $G$. rhopalota was segregated from Dactylella because of sympodially proliferating conidiophores and from Drechsleromyces by a "gangliar" conidiogenesis, i.e., without constriction between denticle and conidium (broad attachment). Only three specific epithets were combined in the genus, which was considered a synonym of Dactylella by Chen et al. (2007b) based on molecular data.

Genicularia Rifai \& R.C. Cooke (1966) — see under Geniculifera.

This illegitimate name, which is a homonym of Genicularia Rouss. (algae), was later replaced by Geniculifera.

Geniculifera Rifai (1975) — Use the older name Arthrobotrys (A) instead of Geniculifera (A) when applying a narrow or moderate generic concept, otherwise use Orbilia (S).

Geniculifera, a replacement name for Genicularia, with the type species $G$. cystosporia, was proposed because of the geniculate conidiophore apex in combination with adhesive networks that capture nematodes. Nine specific epithets have been combined in the genus, mostly by Rifai (Index Fungorum). Since Scholler et al. (1999), its synonymy with Arthrobotrys has been generally recognized.

Golovinia Mekht. (1967) - Use the older name Drechslerella (A) instead of Golovinia (A) when applying a narrow generic concept, otherwise use Arthrobotrys (A) or Orbilia (S).

Golovinia with the type species $G$. bembicodes was segregated from Dactylella and Dactylaria based on fusiform conidia with mostly more than one septum, formed acrogenously or on candelabrelloid conidiophores. A total of 32 specific epithets were combined in the genus by Mekhtieva (1967), comprising nematophagous species with different trapping organs (adhesive networks, adhesive knobs, nonconstricting and constricting rings). Because the type species forms constricting rings, Scholler et al. (1999) placed Golovinia in synonymy with Drechslerella.

Habrostictis Fuckel (1870) — Use Habrostictis (S) when applying a moderate or narrow generic concept, otherwise use Orbilia (S).

A total of 15 specific epithets have been combined in Habrostictis (Index Fungorum), of which only four are considered to be orbiliaceous (Baral et al., unpubl.). When Fuckel erected Habrostictis for H. rubra, a species with erumpent, at first closed then lacerate-fimbriate apothecia, he also placed Stictis ocellata (Pers.) Fr. [三 Pezicula ocellata (Pers.) Seaver] and Schmitzomia chrysophaea (Pers.) Fr. [三 Ramonia chrysophaea (Pers.) Vězda] in this genus. Fuckel placed it in his tribe Stictei between Naevia and Stictis. Boudier (1907), however, restricted Habrostictis to H. carpoboloides and H. lasia (= H. rubra). He referred Stictis ocellata to Ocellaria but considered this genus close to Orbilia. Other authors regarded $H$. rubra to be a member of Orbilia [under the synonymous names $O$. lasia (Berk. \& Broome) Sacc. and O. piloboloides J.H. Haines \& Egger]. Von Höhnel (1917) and Nannfeldt (1932) kept H. rubra in the vicinity of Ocellaria (= Pezicula) and Dermea, until Spooner (1987) and Baral (1994) accepted this species as orbiliaceous.

According to type studies by the first author, H. rubra was found to have several synonyms, including the oldest name Peziza carpoboloides P. Crouan \& H. Crouan. This species (Fig. 2h) belongs to a very large, highly supported monophyletic group of mainly undescribed desiccation-tolerant species (section Habrostictis, Fig. 1), that share elongate, vermiform to filiform spore bodies but differ from the type species in usually having smooth apothecia and capitate paraphyses. In a narrow concept, this group of desiccation-tolerant species is considered a genus of its own, and Habrostictis would be the appropriate name for it. When using a moderate concept, Habrostictis also comprises sections 'Aurantiorubrae' and Helicoon, and, with a broad concept, it is recognized as a subgenus of Orbilia s. 1. (note that some of these groupings are paraphyletic in Fig. 1, and their delimitation is morphology-based). Habrostictis carpoboloides is associated with a vermispora-like asexual morph with small, 1-septate conidia, which was compared with Idriella P.E. Nelson \& S. Wilh. by Haines and Egger (1982). According to molecular phylogenetic analyses, Idriella belongs to Sordariomycetes (Hernández-Restrepo et al. 2015). Most members of the section Habrostictis possess trinacrium-like (Fig. 3q) and some tridentaria-like asexual morphs (Fig. 2v).

Helicoon Morgan (1892) — Use Helicoon (A) when applying a narrow generic concept, otherwise use Orbilia (S).

A total of 27 specific epithets have been combined in Helicoon (Index Fungorum). The main characteristics of the genus are multiseptate, strongly coiled (helicosporous, barrelshaped), hyaline to fuscous conidia, coiled more tightly towards the poles, produced sympodially on denticles on short to long, hyaline to brown conidiophores (Goos et al. 1986).

Similar to the case of the heterogeneous genus Anguillospora, most of these taxa belong to other classes, but only the type species $H$. sessile (Fig. $3 \mathrm{k}$ ) is orbiliaceous with certainty (except for a discrepancy in the sense of rotation of the conidia, Voglmayr 1994). Pfister (1997) obtained H. sessile in an ascospore isolate of Orbilia luteorubella, but this connection was doubted by Hagedorn and Scholler (1999), who found that 
the sequences obtained by Pfister were hypocrealean. However, Pfister's observation could later be confirmed based on a trustable strain of $H$. sessile isolated and subjected to DNA sequencing by $\mathrm{H}$. Voglmayr (pers. comm.) and on an ascospore isolate of O. luteorubella by X.Z. Jiang (pers. comm.) (CGMCC 3.13369, GenBank FJ719770) that produced a Helicoon asexual morph in pure culture.

When using a narrow generic concept of Orbilia, species related to $O$. luteorubella could be placed in a genus of its own, and Helicoon would be available for use. A sexual morph closely related to $O$. luteorubella has Anguillospora rosea as the asexual morph, but the genus Anguillospora is unavailable because its type species belongs in Dothideomycetes (see under Anguillospora).

Section Helicoon (Fig. 1) also includes a highly supported monophyletic subclade for which the very different asexually typified genus Pseudotripoconidium was erected (see there). With a very narrow generic concept, Pseudotripoconidium would be segregated and accepted as distinct from the paraphyletic genus Helicoon.

Orbilia subgenus Hemiorbilia Baral - Use Hemiorbilia (S) by raising it to the generic level rather than Descalsia (A), Radotinea (S), or Trinacrium (A) when applying a moderate or narrow generic concept.

Subgenus Hemiorbilia with the type Orbilia occulta was proposed by Baral (1994) to include taxa with a hemispherical, thick-walled ascus apex (Fig. $2 \mathrm{o}_{3}$ ), in contrast to a truncate, shouldered ascus apex typical of subgenus Orbilia (Fig. $2 \mathrm{k}_{2}$ ). When applying a moderate or narrow concept, we recommend raising subgenus Hemiorbilia to the generic rank (see under the above-listed possibly competing generic names).

Hyalinia Boud., Bull. Soc. Mycol. Fr. 1: 114 (1885) Use Orbilia (S) instead of the illegitimate name Hyalinia (S) when applying a broad concept and Habrostictis (S) when applying a moderate concept.

A total of 58 specific epithets have been combined in Hyalinia (Index Fungorum), most of them by Boudier (1907). The genus was introduced for Helotium crystallinum, a desiccation-sensitive species with a toothed apothecial margin (Fig. 2i, the teeth are composed of long, agglutinated glassy processes) and paraphyses without a distinct apical inflation, but this combination of characters occurs also in many desiccation-tolerant, distantly related species of Orbiliomycetes (e.g., Fig. 2p). The type species is also characterized by narrow, helicoidally twisted ascospores. In 1907, Boudier included species with a smooth margin, many of them today being regarded as members of the Helotiales.

According to Art. 53.3 (ICN), Hyalinia Boud. is an illegitimate homonym of the older, legitimate Hyalina Stackh. (brown algae), despite the different spelling [see Index
Fungorum, note that Kirk et al. (2008) erroneously spelled both names as Hyalinia].

Under a broad generic concept, Hyalinia falls into synonymy with Orbilia (Baral 1994), in which genus its type species competes with another name, $O$. crystallina Rodway, and needs to be renamed as $O$. crenatomarginata. The phylogenetic position of the Hyalinia clade is difficult to determine. We have included it in the paraphyletic section 'Aurantiorubrae' because of morphological similarities to $O$. 'nemaspora' (and $O$. vermiformis), which clusters in a distant clade (Fig. 1).

Hyalorbilia Baral \& G. Marson (2001) - Use the older name Hyalorbilia (S) instead of Brachyphoris (A).

Hyalorbilia was introduced to include five species with $H$. berberidis as the type. At present, it comprises 13 validly combined species. The genus was segregated from typical members of Orbilia because of strong morphological differences, including an ectal excipulum of textura prismatica and \pm homopolar ascospores that usually contain spore bodies near both ends of the spore and asci with a broad, unstalked base arising from croziers (Fig. 2c-e). Later, connections of some Hyalorbilia species to asexual morphs were detected that had previously been described in Dactylella, and for which the genus Brachyphoris was erected (see there). Parasitism on nematode eggs is known for $H$. oviparasitica (Stirling and Mankau 1978) and capture of testaceous rhizopods for 'Dactylella' passalopaga (Drechsler 1936; Barron 2008, see Fig. 5c).

In our molecular phylogenetic analysis, Hyalorbilia forms a highly supported clade with the asexually typified genus Vermispora, which clusters distantly from Orbilia s. 1. (Fig. 1). Based on this phylogenetic relationship and on morphological and ecological similarities in the asexual morph, the generic separation between Hyalorbilia and Vermispora is questionable (see under Vermispora).

Kafiaddinia Mekht. (1978) - Use the older name Dactylellina (A) instead of Kafiaddinia (A) when applying a narrow generic concept, otherwise use Arthrobotrys (A) or Orbilia (S).

Kafiaddinia was erected for K. fusariispora apparently as a replacement name for the illegitimate Dactylosporium. Rubner (1996) regarded the species as a synonym of Dactylellina leptospora, which is the type species of both Dactylosporium and Dactylellina. The two species form stalked adhesive knobs and non-constricting rings, but $K$. fusariispora might represent a different species based on its shorter macroconidia and much shorter microconidia with fewer septa. Only one further species was placed in Kafiaddinia, K. haptospora (Drechsler) Mekht., which, likewise, forms stalked adhesive knobs but no non-constricting rings. 
Laridospora Nawawi (1976) - Use the older name Dactylellina (A) instead of Laridospora (A) when applying a narrow generic concept, otherwise use Arthrobotrys (A) or Orbilia (S).

Laridospora was erected for one species, L. appendiculata, based on long and filiform conidial branches that resemble appendages, the semi-aquatic habitat, and non-predacious habit. However, Rubner (1996: 98, as Monacrosporium tentaculatum A. Rubner \& W. Gams) showed that the type species forms stalked adhesive knobs. No further taxa were combined in Laridospora. Scholler et al. (1999) placed the genus in synonymy with Dactylellina.

Lecophagus M.W. Dick (1990) - At present, Lecophagus (A) is without a competing name.

Lecophagus with the type species L. fasciculatus was proposed for two species. Up to now, six specific epithets have been used in the genus, which is recognized for asexual morphs with very broad mycelial hyphae and the ability to capture rotifers and tardigrades by means of adhesive pegs (Fig. 5a, b). The conidia (Fig. 3g) resemble those of Vermispora or Anguillospora, and we have evidence of a connection to an undescribed sexual morph (Fig. 2b, Baral et al., unpubl.) that forms minute white apothecia on xeric wood and bark, with broad anchoring hyphae emerging from dead rotifer bodies.

Phylogenetically, the monophyletic genus falls in the Orbiliomycetes (Tanabe et al. 1999), which is supported by ascospore morphology: the living spores contain a conspicuous globose spore body close to one end (Fig. $2 b_{2}$ ). In our analysis, Lecophagus clusters in a highly supported clade with two unpublished, mainly resinicolous genera, 'Lilapila' ined. and 'Amphosoma' ined. (Fig. 1), which are morphologically very different from Lecophagus and for which no predatory capabilities are known.

Since no competing sexual or asexual morph name is known, Lecophagus will be extended to include also the sexual morph. Recently, Magyar et al. (2016) widened the generic concept by including a species with sessile adhesive knobs that capture nematodes.

Microdochiella Hern.-Restr. \& Crous (2015) - Use the older name Vermispora (A) when considering both as congeneric.

Microdochiella was erected for a single species, M. fusarioides, which was isolated from Phytophthora oospores. Morphologically, it is very similar to Vermispora, and its ecology was considered a main difference. However, the authors overlooked that the capability to invade spores of oomycetes occurs in both genera. LSU rDNA sequences of M. fusarioides clustered with Vermispora spp. in HernándezRestrepo et al.'s (2015) phylogenetic analysis, though in a distinct clade. The same result is obtained when the ITS region is analyzed (unpubl.).
At present, we consider separation of Microdochiella from Vermispora at the generic level as questionable. No sexual morph is known in either of the two asexually typified genera. Both resemble also the brachyphoris-like asexual morph of the closely related genus Hyalorbilia (see under Vermispora).

Monacrosporiella Subram. (1978) — Use the older name Arthrobotrys (A) instead of Monacrosporiella (A) when applying a narrow or moderate generic concept, otherwise use Orbilia (S).

Monacrosporiella was erected for M. megalospora, a species forming adhesive networks; one further species was added later. As in Monacrosporium, the genus was based on conidiophores that produce a single acrogenous fusiform conidium, differing in a "distinct basal hilum" (Subramanian 1978), which is a conidial scar "modified by a lump-like deposit of opaque material" (Drechsler 1954). Subramanian believed that, in contrast to Monacrosporiella, the conidia of Monacrosporium were not blastic but "gangliar", as they were formed by the transformation of the swollen tip of a conidiophore and, therefore, lacked the "conspicuous basal conidial scar". Monacrosporiella has rarely been used and is today regarded as a synonym of Arthrobotrys.

Monacrosporium Oudem. (1885) - Use the older name Arthrobotrys (A) instead of Monacrosporium (A) when applying a narrow or moderate generic concept, otherwise use Orbilia (S).

Monacrosporium was erected for M. elegans and M. subtile Oudem. with long, unbranched conidiophores with single acrogenous conidia, which are fusiform in M. elegans (Fig. 4n) and clavate in M. subtile. The lectotype species M. elegans forms adhesive networks, whereas $M$. subtile is possibly non-predacious (Rubner 1996). By including also species with apically branched, candelabrelloid conidiophores, a total of 70 , mainly predacious, species have been added to the genus (Index Fungorum). By accepting all types of orbiliaceous trapping organs, Rubner (1996) restricted Monacrosporium to nematophagous taxa in her revision of the Dactylella-Monacrosporium complex. Scholler et al. (1999) considered M. elegans as congeneric with A. superba, the type species of Arthrobotrys, despite very different conidiophores and conidia. This congenericity is supported by rDNA data (see Fig. 1).

Mycoceros D. Magyar \& Z. Merényi (2017) - At present, Mycoceros (A) is without competing names.

Like Retiarius, Mycoceros was introduced for a species that captures wind-borne pollen grains (M. antennatissimus). Its conidia resemble those of Dwayaangam but are usually three times dichotomously branched. Mainly molecular data distinguish Mycoceros from Retiarius. In Magyar et al.'s (2017a, b) molecular phylogenetic analysis of different classes of 
ascomycetes, it nested with high support as a sister clade to all the remaining Orbiliomycetes; nevertheless, it was considered to belong in this class.

Nematophagus Mekht. (1975) - Use the older name Arthrobotrys (A) instead of Nematophagus (A) when applying a narrow or moderate generic concept, otherwise use Orbilia (S).

Nematophagus was erected for one species, $N$. azerbaijanicus. The genus closely resembles the classical concept of Arthrobotrys because of its arthrobotryoid conidiophores having nodules aggregated on \pm swollen nodes. It was segregated based on conidia that tend to form more than one septum. Five further taxa were later included in the genus by Mekhtieva, although only some of them exceptionally showed conidia with more than one septum. Most of them, including the type species, capture nematodes by adhesive networks, but one by constricting rings.

Orbilia Fr. (1836) - Use Orbilia (S) in a wide or narrow sense, depending on the applied concept.

Orbilia is the oldest available generic name of all competing sexually and asexually typified genera recognized in the Orbiliomycetes. About 260 specific epithets have been validly combined in Orbilia (Index Fungorum), of which ca. 80 are accepted at present.

When Orbilia was firstly established, it contained two species, O. leucostigma and $O$. xanthostigma. Although currently believed to be lectotypified by Clements and Shear (1931) with O. leucostigma, the earliest known lectotypification was that by Bachmann (1909) based on O. xanthostigma. Type material does not exist for either of these, and the original descriptions are without ascospore data. A neotype will be proposed for $O$. xanthostigma (Baral et al. unpubl.) in the sense of $O$. delicatula (P. Karst.) P. Karst. Orbilia xanthostigma and $O$. leucostigma are exceptional within the Orbiliomycetes by their warted spores (Fig. 2k).

Depending on the applied concept, the name Orbilia will be used at the generic level for section, subgenus, or genus Orbilia as represented in Fig. 1.

Orbiliaster Dennis (1954) - Protect Drechslerella (A) over the older Orbiliaster (S) when applying a narrow generic concept, otherwise use Arthrobotrys (A) or Orbilia (S).

The genus Orbiliaster was erected for one species, $O$. pilosus, to accommodate an orbiliaceous sexual morph with septate hairs (Fig. 2j). The single later included species is distantly related and a member of section 'Aurantiorubrae'. An isolate from a sexual morph tentatively referred to O. pilosus (Baral et al., unpubl.) produced constricting rings in culture, and molecular data confirmed its placement in the
Drechslerella clade (Pfister 1997: 16-17, as Orbilia sp./ Monacrosporium ?doedycoides). This suggests that Orbiliaster is an older synonym of Drechslerella. For reasons stated under Drechslerella, we propose to protect this name over Orbiliaster.

Orbiliella Kirschst. (1938) - Use the older name Arthrobotrys (A) instead of Orbiliella (S) when applying a moderate or narrow generic concept, otherwise use Orbilia (S).

Orbiliella was based on a single species, $O$. armeniaca, and no further taxa were later added to the genus. The holotype was re-examined (Baral et al., unpubl.) and found to fit Orbilia auricolor agg. The asexual morph growing in association on the natural substrate matches Arthrobotrys cladodes or A. superba (Fig. 4o), which were both found to be connected to O. auricolor. Orbiliella is a clear synonym of the older Arthrobotrys and should not be used.

Paradactylella Matsush. (1993) - Protect Hyalorbilia (S) over the older Paradactylella (A) in case of congenericity.

According to Seifert et al. (2011), Paradactylella is a synonym of Dactylella. The short conidiophores would, however, rather point to Brachyphoris. Thus, it cannot be excluded that the genus Paradactylella with, so far, only one species, $P$. peruviana, may provide an older name for the genera Brachyphoris and Hyalorbilia. However, although not specifically mentioned, conidial secession could be rhexolytic, according to the original drawing (re-drawn in Seifert et al. 2011), which would question a relationship with the Orbiliomycetes.

In case Paradactylella peruviana can be restudied including DNA sequence analysis, and is found to fit Hyalorbilia, we prefer to protect Hyalorbilia because of the many otherwise required name changes.

Patinella Sacc., Grevillea 4: 22 (1875) - not orbiliaceous.

The genus was proposed for one species, $P$. hyalophaea Sacc. Over 60 species have been combined in Patinella (Index Fungorum). Nannfeldt (1932) placed the genus in a very restricted sense in Orbiliaceae because of capitate paraphyses and a paraplectenchymatic excipulum in the type species. Molecular data gained from a recent specimen described in Baral and Carter (2013) revealed that $P$. hyalophaea is very distant from Orbiliomycetes but related to Holwaya Sacc. (Tympanidaceae, Leotiomycetes).

Pedilospora Höhn. (1902) — Use the older name Orbilia (S) instead of Pedilospora (A).

Peek and Solheim (1958) and Matsushima (1981) considered Pedilospora as a synonym of Dicranidion, based on their belief that the type species of the two genera (P. parasitans 
and D. fragile) and also P. episphaeria Höhn. and $P$. ramularioides Bubák might be conspecific. Pedilospora parasitans was described by Höhnel (1902) as growing "In Helotio citrino (?) parasitica" ( E Calycina citrina $\equiv$ Bisporella citrina), and, possibly, Höhnel confused Orbilia eucalypti (asexual morph D. fragile) with the helotialean Calycina citrina. Drechsler (1934) included a species in Pedilospora, $P$. dactylopaga Drechsler, which is exceptional in preying on testaceous rhizopods and having very long conidiophores. Four further species have been combined in Pedilospora, according to Index Fungorum.

Pseudorbilia Ying Zhang, Z.F. Yu, Baral \& K.Q. Zhang (2007) — Pseudorbilia (S) is, at present, without competing names.

Pseudorbilia was erected for Ps. bipolaris, in which both ends of the ascospores contain a spore body (bipolar spore body arrangement, Fig. 2a). In this respect, the fungus resembles Hyalorbilia and particularly 'Amphosoma' ined. (Fig. 2g), from which it differs, e.g., in asci with a truncate, shouldered apex (similar to Fig. $2 \mathrm{k}_{2}$ ). No further species was, so far, included in the genus, no asexual morph is known, and no molecular data are available.

Pseudotripoconidium Z.F. Yu \& K.Q. Zhang (2011) Use Pseudotripoconidium (A) or Helicoon (A) when applying a narrow generic concept, otherwise use Habrostictis (S) or Orbilia (S).

Yu et al. (2011) introduced Pseudotripoconidium to accommodate $P$ s. sinense for an asexual morph obtained in an ascospore isolate of an Orbilia referred to $O$. aff. luteorubella. Its inversely pyramidal, non-septate conidia possess more or less pronounced distal nipples and are formed on denticles at the conidiophore apex (Fig. 3j). Shortly after, some closely related species were also found to produce this peculiar type of asexual morph, e.g., O. acicularis Baral \& Hong Y. Su (Su et al. 2011), but the asexual morph was not given a separate name. The genus Pseudotripoconidium resembles Tripoconidium, which differs in septate conidia formed singly at the conidiophore tip.

In the morphology of the sexual morph, this group does not markedly differ from $O$. luteorubella and allied taxa with anguillospora- and helicoon-like conidia very different from Pseudotripoconidium. In molecular phylogenetic analyses, Pseudotripoconidium forms a highly supported monophyletic clade, whereas the group with anguillospora- and helicoonlike conidia appears paraphyletic. The two groups form a monophyletic clade which, under a moderate generic concept, would receive the older name Habrostictis. When applying a narrow generic concept, Pseudotripoconidium and Helicoon can either be used as two separate genera or Pseudotripoconidium can be regarded as a synonym of Helicoon (Fig. 1).
Radotinea Velen. (1934) - Use Orbilia in the broad concept, or, by raising Hemiorbilia (S) to the generic level (existing at present only at the infrageneric level), use Hemiorbilia rather than the unclear Radotinea (S) when applying a moderate or narrow generic concept.

The single species included in Radotinea, $R$. caudata, was described with solid (glassy), 15-35 $\mu \mathrm{m}$ long hairs with a lumen only at the very base, and spores with a thin tail. Velenovský (1934) saw a relationship to Orbilia, but placed it in the Hyaloscyphaceae because of the hairs. The original description appears to refer to $O$. aristata or an undescribed very close relative of it ( $O$. 'subaristata' ined.), but a further, comparatively distant species $(O$. 'pseudoaristata' ined.) cannot be excluded with certainty. Since no apothecia could be found in the holotype, we consider $R$. caudata as a nomen dubium. Radotinea competes with the subgenus Hemiorbilia when using a moderate or narrow generic concept. We recommend not using Radotinea because the type material does not permit to clarify the identity of the species, and the name has never been taken up by other authors.

Retiarius D.L. Olivier (1978) - Retiarius (A) is, at present, without competing names.

Retiarius was introduced for two species that capture windborne pollen grains. Two further species will be added to the genus (Magyar et al. 2017b). The type species, $R$. superficiaris D.L. Olivier, has trinacrium- to tripospermum- or dwayaangam-like conidia. The second included species, $R$. bovicornutus D.L. Olivier, was considered to belong to Trinacrium by Matsushima (1993: 30). Magyar et al. (2017a, b) gained rDNA sequences from the ex-type cultures of the two Retiarius species (IMI 223459 and 223460) and one of their new species, which, in their phylogenetic analysis, formed a separate group within the clade containing Lecophagus.

Roigiella R.F. Castañeda (1984) — Use the older name Arthrobotrys (A) instead of Roigiella (A) when applying a narrow or moderate generic concept, otherwise use Orbilia (S).

Only one species, $R$. lignicola, has been combined in Roigiella. According to Seifert et al. (2011), the genus is a synonym of Arthrobotrys in its narrow sense. An unpublished sequence of the ex-type strain (CBS 222.85) clustered near Arthrobotrys dendroides Kuthub., Muid \& J. Webster (alignment tool in http://www.cbs.knaw.nl/collections/). Both species form synnemata. No trapping organs were reported in pure culture of $R$. lignicola, probably because no nematodes were added.

Tricellula Beverw., Antonie van Leeuwenhoek 20: 15 (1954) — Probably not orbiliaceous. 
The genus Tricellula was originally proposed for T. inaequalis Beverw., a species with 3-celled holoblastic stauroconidia composed of a stalk and usually two arms, with strong constrictions at the indistinct septa, formed on dichotomously branched conidiophores. Nine species have been included according to Index Fungorum. Matsushima (2003) obtained T. inaequalis and its sexual morph in pure culture from a Japanese soil isolate, and described the sexual morph in Orbilia as a new species, O. tricellularia Matsush. He placed it in subgenus Hemiorbilia, obviously because of the slightly thickened apical wall of immature asci. No information on the iodine reaction was supplied. Whether a spore body or other organelles occurred in the ascospores remains unclear, because all elements were illustrated in the dead state.

The conical ascus apex and the presence of croziers excludes Orbilia; also, a relation to Hyalorbilia does not seem very probable. Probably, O. tricellularia belongs to the Helotiales rather than the Orbiliomycetes. A more detailed morphological study should be carried out on this species to find out its genuine placement. Molecular data do not seem to exist for any of the species of Tricellula. Volucrispora Haskins was synonymized with Tricellula by von Arx (1970), whereas Volucrispora graminea Ingold et al., a species added later, was segregated in the genus Ypsilina J. Webster et al. (Descals et al. 1999). A BLAST search of three ITS sequences of Y. graminea in GenBank against the nucleotide database of the NCBI (http://www.ncbi.nlm.nih.gov) revealed relationships with Oculimacula Crous \& W. Gams (= Helgardia Crous \& W. Gams) and other members of Ploettnerulaceae (Helotiales) , where it clusters also in the analysis of Baschien et al. (2013).

Tridentaria Preuss, Linnaea 25: 74 (1852) - Use Tridentaria (A) (in the sense of Drechsler 1937b) only in the form of "tridentaria-like" when referring to conidial shape.

The original description was based on Tridentaria alba Preuss, which forms acervuli containing unbranched conidia arranged in fascicles that suggest a branched conidium. The brief description is inadequate for modern systematics. Because the type specimen did not bear a fungus which agreed with the protologue (van der Aa and van Oorschot 1985), the identity of $T$. alba remains unclear. Probably, it represented a non-orbiliaceous fungus.

Drechsler (1937b, 1940, 1962, 1964) adopted the name Tridentaria to accommodate four new hyphomycetous, nematode- (T. implicans Drechsler) and, particularly, rhizopod-trapping species (T. carnivora Drechsler, T. glossopaga Drechsler, and T. tylota Drechsler). Three further species for which no trapping capabilities are known have been added to the genus by other authors (Index Fungorum), one of which (T. setigera Grove) was later transferred to
Tetracladium De Wild. and belongs to the Helotiales based on molecular data.

With exclusion of the type species and T. setigera, Tridentaria represents a group of apparently orbiliaceous asexual morphs with a peculiar conidial shape, being somewhat intermediate between Dicranidion and Trinacrium, with three or more \pm equal arms and a stipe of varying length, formed on short or long conidiophores. In contrast to Dicranidion and Trinacrium, the arms are usually constricted at the branching point, which enables a considerable motility of each arm (Fig. 3v). Drechsler's three rhizopod-capturing species might belong to Hyalorbilia because of predacious similarities to 'Dactylella' passalopaga (see under Brachyphoris), whereas the DNA sequences of two strains of Tridentaria (CBS, identified as T. implicans and T. subuliphora Matsush.) cluster in the series Orbilia (Fig. 1). A few species of the section Habrostictis were found to possess undescribed tridentaria-like asexual morphs (Baral et al., unpubl.), e.g., O. septispora Baral (Fig. 3v).

Because of the unsettled identity of the type species, Tridentaria should not be used as a holomorph name, but only for characterizing asexual morphs when referring to them as "tridentaria-like". The type species of the aquatic hyphomycete genus Flabellocladia Nawawi (1985), F. gigantea Nawawi, strongly resembles orbiliaceous asexual morphs of Tridentaria, but the large size of the conidia would be unusual. The type should be investigated by molecular methods to elucidate its phylogenetic relationship.

Trinacrium Riess (1852) - Use Orbilia (S) in the broad concept. When applying a moderate or narrow generic concept, raise Hemiorbilia (S) to the genus rank (existing at present only at the infrageneric level) and use it rather than the unclear Trinacrium (A).

Trinacrium was erected for T. subtile, and 16 species were later added to the genus (Index Fungorum). The main characteristics are the triradiate (Y-shaped), hyaline conidia with a main axis (stipe), and two divergent, usually equal arms formed by dichotomous branching. A type specimen does not seem to exist and a culture was obviously not made.

Conidia of the trinacrium-type occur in various groups of Orbiliomycetes (Fig. 1) and are typical of, e.g., many members of the Habrostictis clade (Fig. 3q), but also the subgenus Hemiorbilia (Fig. 3s), or a clade around $O$. pilifera Baral \& R. Galán, in which the arms are bent downwards (Fig. 3t). Trinacrium iridis Ts. Watan. is nematophagous and belongs to Arthrobotrys, and, also, species of Hyalorbilia (Fig. 3r) and 'Amphosoma' ined. (Fig. $3 u$ ) have trinacrium-like asexual morphs. The type species cannot be identified with certainty, but it is probably the asexual morph of one of a couple of species of the section Hemiorbilia. Because of this uncertainty, we do not recommend to use Trinacrium as a generic name. 
Tripoconidium Subram. (1978) - Use Arthrobotrys (A) instead of Tripoconidium (A, in case of congenericity) when applying a moderate generic concept, use Orbilia (S) when applying a broad concept.

Only one species was combined in Tripoconidium, which is characterized by inversely pyramidal, multiseptate conidia with terminal nipple-like protrusions, formed singly at the tip of long conidiophores (for the differences to Pseudotripoconidium, see there). The species seems to belong to the Orbiliomycetes as inferred from its morphology and because it is weakly predacious on nematodes. Since it does not form conspicuously differentiated trapping organs, and since no ex-type culture or a DNA sequence is available, its placement within the nematode-trapping groups of Arthrobotrys s. 1. remains unclear.

Vermispora Deighton \& Piroz. (1972) — is presently without competing names (but see under Microdochiella); protect Hyalorbilia (S) over Vermispora

\section{(A) when considering both genera as congeneric.}

Vermispora was erected for $V$. grandispora based on large, elongate-fusoid phragmoconidia that are slightly curved towards the ends and are formed in small number on rather short, sympodial conidiophores. Further five species were later added to the genus. Chen et al. (2007a, c) provided DNA sequences for three of them, but excluded V. obclavata V. Rao \& de Hoog for morphological reasons (e.g., faintly pigmented conidiophores). DNA data of the type species, which is only known from the type collection and obviously had not been taken into culture, is not available. One of the species with available DNA data, V. fusarina Burghouts \& W. Gams (Fig. 3a), is known to parasitize nematode eggs.

Available sequences of Vermispora form a highly supported monophyletic clade with Hyalorbilia distant from Orbilia s. 1. (Fig. 1). Vermispora would provide an older name for Hyalorbilia when applying a wider generic concept, based on its close molecular affiliation with Hyalorbilia, the paraphyly of Hyalorbilia, and morphological as well as ecological similarities in the asexual morphs (parasitism on nematode eggs occurring in both genera). Sexual morphs are unknown in Vermispora. In our opinion, merging of the two genera should consider also the morphology of the sexual morph; therefore, we refrain hereof at present. Since more combinations would be necessary when adopting Vermispora, we recommend protecting Hyalorbilia with presently 13 combined taxa over Vermispora (see also under Microdochiella) in case they are congeneric.

Morphologically, Vermispora resembles unpublished asexual morphs in various groups of Orbilia s. 1., for instance, in species related to $O$. aurantiorubra (Fig. 3b, c, f) or in section 'Lentiformes' (Fig. 3d, e) (see Fig. 1). Because of a morphological similarity of Vermispora to asexual morphs observed within Orbilia s. 1., we use the term "vermispora-like" for them, but this type of conidia is not sharply separated from the longer conidia that resemble those of Anguillospora.

Woroninula Mekht. (1979) — Use the older name Arthrobotrys (A) instead of Woroninula (A) when applying a narrow or moderate generic concept, otherwise use Orbilia (S).

Woroninula with the type species W. polycephala was proposed for three species based on 2-4-septate, large, elongate fusoid to ellipsoid conidia formed on arthrobotryoid conidiophores. All three species form adhesive networks, and no further taxa have later been added to the genus. Scholler et al. (1999) referred it to Arthrobotrys.

Acknowledgments We thank Hongyan Su (Dali), Zefen Yu and Ying Zhang (Kunming), and XianZhi Jiang (Beijing) for providing documentations of Chinese collections, Hermann Voglmayr for a sequence of Helicoon sessile, and Antonio Roldán for the permanent slides of Descalsia cruciata. L. Marvanová acknowledges the financial support from the Czech Collection of Microorganisms.

Open Access This article is distributed under the terms of the Creative Commons Attribution 4.0 International License (http:// creativecommons.org/licenses/by/4.0/), which permits unrestricted use, distribution, and reproduction in any medium, provided you give appropriate credit to the original author(s) and the source, provide a link to the Creative Commons license, and indicate if changes were made.

\section{References}

Ando K (1992) Differentiation patterns of stauroconidia based on unusual conidia produced by Trinacrium subtile. Trans Mycol Soc Jpn 33: 223-229

Bachmann FM (1909) Discomycetes in the vicinity of Oxford, Ohio. Contributions from the botanical laboratory of Miami University I. Proc Ohio State Acad Sci 5:18-70

Baral HO (1992) Vital versus herbarium taxonomy: morphological differences between living and dead cells of ascomycetes, and their taxonomic implications. Mycotaxon 44:333-390

Baral HO (1994) Comments on "Outline of the ascomycetes-1993". Syst Ascomycetum 13:113-128

Baral HO, Carter A (2013) Patinella hyalophaea Sacc.- - rediscovered in New Brunswick, Canada. Ascomycete.org 5:91-96

Barron GL (2008) War of the microworlds. Available online at: http:// www.uoguelph.ca/ gbarron/2008/passalop.htm

Baschien C, Marvanová L, Szewzyk U (2006) Phylogeny of selected aquatic hyphomycetes based on morphological and molecular data. Nova Hedw 83:311-352

Baschien C, Tsui CKM, Gulis V, Szewzyk U, Marvanová L (2013) The molecular phylogeny of aquatic hyphomycetes with affinity to the Leotiomycetes. Fungal Biol 117:660-672

Belliveau MJR, Bärlocher F (2005) Molecular evidence confirms multiple origins of aquatic hyphomycetes. Mycol Res 109:1407-1417

Boudier É (1907) Histoire et classification des discomycètes d'Europe. Librairie des Sciences Naturelles, Paris

Brefeld O (1891) Untersuchungen aus dem Gesammtgebiete der Mykologie, 10. Ascomyceten II. Münster/Westfalen, Germany 
Cannon PF, Kirk PM (2000) The philosophy and practicalities of amalgamating anamorph and teleomorph concepts. Stud Mycol 45:19-24

Chen J, Xu LL, Liu B, Liu XZ (2007a) Taxonomy of Dactylella complex and Vermispora. I. generic concepts based on morphology and ITS sequences data. Fungal Divers 26:73-83

Chen J, Xu LL, Liu B, Liu XZ (2007b) Taxonomy of Dactylella complex and Vermispora. II. the genus Dactylella. Fungal Divers 26:85-126

Chen J, Xu LL, Liu B, Liu XZ (2007c) Taxonomy of Dactylella complex and Vermispora. III. a new genus Brachyphoris and revision of Vermispora. Fungal Divers 26:127-142

Clements FE, Shear CL (1931) The genera of fungi. H.W. Wilson Co., New York

Descals E, Chauvet E (1992) Diversité des champignons ingoldiens de quelques rivières du sud-ouest de la France. Nova Hedwigia 54:83-96

Descals E, Marvanová L, Webster J (1999, “1998”) New taxa and combinations of aquatic hyphomycetes. Can J Bot 76:1647-1659

Drechsler C (1934) Pedilospora dactylopaga n. sp., a fungus capturing and consuming testaceous rhizopods. J Wash Acad Sci 24:395-402

Drechsler C (1936) A Fusarium-like species of Dactylella capturing and consuming testaceous rhizopods. J Wash Acad Sci 26:397-404

Drechsler C (1937a) Some hyphomycetes that prey on free-living terricolous nematodes. Mycologia 29:447-552

Drechsler C (1937b) A species of Tridentaria preying on Difflugia constricta. J Wash Acad Sci 27:391-398

Drechsler C (1940) Three new hyphomycetes preying on free-living terricolous nematodes. Mycologia 32:448-470

Drechsler C (1954) Some hyphomycetes that capture eelworms in southern states. Mycologia 46:762-782

Drechsler C (1962, “1961”) Some clampless hyphomycetes predacious on nematodes and rhizopods. Sydowia 15:9-25

Drechsler C (1964) A Tridentaria subsisting on testaceous rhizopods and Pythium oospores. Sydowia 18:359-363

Eriksson OE, Baral HO, Currah RS, Hansen K, Kurtzman CP, Læssøe T, Rambold G (2003) Notes on ascomycete systematics Nos 3580 3623. Myconet 9:91-103

Gams W, Rubner A (1997) (1285-1286) Proposals to reject the names Dactylium and D. candidum (Fungi). Taxon 46:335-336

Gönczöl J, Marvanová L (2002) Anguillospora mediocris sp. nov. from streams in Hungary. Czech Mycol 53:309-317

Goos RD, Abdullah SK, Fisher PJ, Webster J (1986) The anamorph genus Helicoon. Trans Br Mycol Soc 87:115-122

Grove WB (1884) New or noteworthy fungi. J Bot (London) 22:195-201

Hagedorn G, Scholler M (1999) A reevaluation of predatory orbiliaceous fungi. I. phylogenetic analysis using rDNA sequence data. Sydowia 51:27-48

Haines JH, Egger KN (1982) A new species of Orbilia from Canada. Mycotaxon 16:107-113

Hawksworth DL (2011) A new dawn for the naming of fungi: impacts of decisions made in Melbourne in July 2011 on the future publication and regulation of fungal names. MycoKeys 1:7-20

Hernández-Restrepo M, Groenewald JZ, Crous PW (2015) Taxonomic and phylogenetic re-evaluation of Microdochium, Monographella and Idriella. Persoonia 36:57-82

Katoh K, Standley DM (2013) MAFFT multiple sequence alignment software version 7: improvements in performance and usability. Mol Biol Evol 30:772-780

Kirk PM, Cannon PF, Minter DW, Stalpers JA (2008) Ainsworth \& Bisby's dictionary of the fungi, 10th edn. CABI, Wallingford

Kohlmeyer J, Baral HO, Volkmann-Kohlmeyer B (1998) Fungi on Juncus roemerianus. 10. A new Orbilia with ingoldian anamorph. Mycologia 90:303-309

Li Y, Jeewon R, Hyde KD, Mo MH, Zhang KQ (2006) Two new species of nematode-trapping fungi: relationships inferred from morphology, rDNA and protein gene sequence analyses. Mycol Res 110:790-800
Magyar D, Merényi Z, Bratek Z, Baral HO, Marson G (2016) Lecophagus vermicola sp. nov., a nematophagous hyphomycete with an unusual hunting strategy. Mycol Prog 15:1137-1144

Magyar D, Merényi Z, Udvardy O, Kajtor-Apatini D, Körmöczi P, Fülöp A, Bratek Z, Kredics L (2017a) Mycoceros antennatissimus gen. et sp. nov.: a mitosporic fungus capturing pollen grains. Mycol Prog. doi:10.1007/s11557-017-1275-3

Magyar D, Merényi Z, Körmöczi P, Bratek Z, Kredics L (2017b) Two new species of Retiarius (hyphomycetes) from pollen grains. Nova Hedw (in press)

Matsushima T (1981) Matsushima mycological memoirs no. 2. Kobe, Japan

Matsushima T (1993) Matsushima mycological memoirs no. 7. Kobe, Japan

Matsushima T (2003, “2001”) Matsushima mycological memoirs no. 10. Kobe, Japan

Matsushima T (2005) Matsushima mycological memoirs no. 1 (1980) to no. 10 (2001), electronic version (with additional illustrations)

Mekhtieva NA (1967) On systematics of some nematophagous fungi. Mikol Fitopatol 1:269-279 (in Russian)

Nakagiri A, Tubaki K (1983) Lindra obtusa, a new marine ascomycete and its Anguillospora anamorph. Mycologia 75:487-497

Nannfeldt JA (1932) Studien über die Morphologie und Systematik der nicht-lichenisierten inoperculaten Discomyceten. Nova Acta Regiae Soc Sci Ups 4(8):1-368

Nawawi A (1985) Another aquatic hyphomycete genus from foam. Trans Brit Mycol Soc 85:174-177

Peek CA, Solheim WG (1958) The hyphomycetous genera of HW Harkness and the ascomycetous genus Cleistosoma Harkn. Mycologia 50:844-861

Pfister DH (1997) Castor, Pollux and life histories of fungi. Mycologia 89:1-23

Qiao M, Zhang Y, Li SF, Baral HO, Weber E, Su HY, Xu JP, Zhang KQ, Yu ZF (2012) Orbilia blumenaviensis and its Arthrobotrys anamorph. Mycol Prog 11:255-262

Qiao M, Li JY, Baral HO, Zhang Y, Qian WY, Su HY, Yu ZF (2015) Orbilia yuanensis sp. nov. and its anamorph. Mycol Prog 14:1. doi: 10.1007/s11557-015-1022-6

Quijada L, Baral HO, Jaen-Molina R, Weiß M, Caujapé-Castells J, Beltrán-Tejera E (2014) Phylogenetic and morphological circumscription of the Orbilia aurantiorubra group. Phytotaxa 175:1-18

Rossman AY, Cavan Allen W, Braun U, Castlebury LA, Chaverri P, Crous PW, Hawksworth DL, Hyde KD, Johnston P, Lombard L, Romberg M, Samson RA, Seifert KA, Stone JK, Udayanga D, White JF (2016) Overlooked competing asexual and sexually typified generic names of Ascomycota with recommendations for their use or protection. IMA Fungus 7:289-308

Rubner A (1996) Revision of predacious hyphomycetes in the DactylellaMonacrosporium complex. Stud Mycol 39:1-134

Schenck S, Kendrick WB, Pramer D (1977) A new nematode-trapping hyphomycete and a reevaluation of Dactylaria and Arthrobotrys. Can J Bot 55:977-985

Scholler M, Hagedorn G, Rubner A (1999) A reevaluation of predatory orbiliaceous fungi. II. A new generic concept. Sydowia 51:89-113

Seifert KA, Gams W, Crous PW, Samuels GJ (2000) Molecules, morphology and classification: towards monophyletic genera in the ascomycetes. Introduction. Stud Mycol 45:1-4

Seifert K, Morgan-Jones G, Gams W, Kendrick B (2011) The genera of hyphomycetes. CBS Biodivers Ser 9:1-997

Sherbakoff CD (1933) A new fungus parasitic on nematodes. Mycologia 25:258-262, pl 35

Soprunov FF (1958) Kishchnye griby-gifomitseti i ikh primenenie v bor'be s patogennymi nematodami [English translation 1966: Predacious hyphomycetes and their application in the control of pathogenic nematodes]. Akademii Nauk Turkmenskoi SSR, Ashkhabad 
Spooner BM (1987) Helotiales of Australasia: Geoglossaceae, Orbiliaceae, Sclerotiniaceae, Hyaloscyphaceae. Bibl Mycol 116:1-711

Stamatakis A (2014) RAxML version 8: a tool for phylogenetic analysis and post-analysis of large phylogenies. Bioinformatics 30:13121313

Stirling GR, Mankau R (1978) Dactylella oviparasitica, a new fungal parasite of Meloidogyne eggs. Mycologia 70:774-783

Su HY, Zhang Y, Baral HO, Yang XY, Mo MH, Cao YH, Chen MH, Yu ZF (2011) Four new species of Orbiliaceae from Yunnan, China. Mycol Prog 10:373-381

Subramanian CV (1978, “1977”) Revisions of hyphomycetes I. Kavaka 5:93-98

Swe A, Jeewon R, Hyde KD (2008) Nematode-trapping fungi from mangrove habitats. Cryptog Mycol 29:333-354

Tanabe Y, Nagahama T, Saikawa M, Sugiyama J (1999) Phylogenetic relationship of Cephaliophora to nematophagous hyphomycetes including taxonomic and nomenclatural emendations of the genus Lecophagus. Mycologia 91:830-835

van der Aa HA, van Oorschot CAN (1985) A redescription of some genera with staurospores. Persoonia 12:415-425

van Oorschot CAN (1985) Taxonomy of the Dactylaria complex, V. A review of Arthrobotrys and allied genera. Stud Mycol 26:61-96

Velenovský J (1934) Monographia Discomycetum Bohemiae. Vols. 1 and 2. Pragae
Voglmayr H (1994) Die aero-aquatischen Pilze in Österreich. Master's thesis, University of Vienna

von Arx JA (1970) Genera of fungi sporulating in pure culture. Cramer, Lehre

von Höhnel F (1917) Fragmente zur Mykologie (XIX. Mitteilung, Nr. 1001-1030). Sitzungsber Kaiserl Akad Wiss Wien, Math-Naturwiss K1. Abt I 126:283-352

Webster J (1961) The Mollisia perfect state of Anguillospora crassa. Trans Br Mycol Soc 44:559-564

Webster J, Descals E (1979) The teleomorphs of water-borne hyphomycetes from fresh water. In: Kendrick B (ed) The whole fungus, vol 2. National Museum of Canada and Kananaskis Foundation, Ottawa, pp 419-451

Yu ZF, Qiao M, Zhang Y, Baral HO, Zhang KQ (2007a) Orbilia vermiformis sp. nov. and its anamorph. Mycotaxon 99:271-278

Yu ZF, Zhang Y, Qiao M, Zhang KQ (2007b) Orbilia dorsalia sp. nov., the teleomorph of Dactylella dorsalia sp. nov. Cryptog Mycol 28: $55-63$

Yu ZF, Kong YJ, Zhang Y, Qiao M, Guo JW, Zhang KQ (2009) A new Dactylella species from Orbilia alba. J Microbiol 47:265-269

Yu ZF, Qiao M, Zhang Y, Qin L, Zhang KQ (2011) Pseudotripoconidium, a new anamorph genus connected to Orbilia. Mycologia 103:164 173

Zhang Y, Yu ZF, Baral HO, Qiao M, Zhang KQ (2007) Pseudorbilia gen. nov. (Orbiliaceae) from Yunnan, China. Fungal Divers 26:305-312 